الدورية العلمية لكلية الفنون الجميلة - جامعة الإسكندرية

SJPA Scientific Journal of the Faculty of Fine Arts Alexandria University

Print ISSN: 2356-8038

Online ISSN: 2535-227x

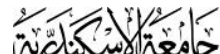

ALEXANDRIA

U NIVERSITY

\title{
روية لسينوجرافيا باليه شهرزاد بين التراث الشعبي والوسائط الحديثة
}

(بحث تطبيقي تم عرضه بقاعة العرض الرئيسية بمبنى مظلوم بكلية الفنون الجميلة جامعة الإسكندرية بتاريخ 4 / 11 / 2017)

د.بسمة خليل إبر اهيم خليل1

الملخص

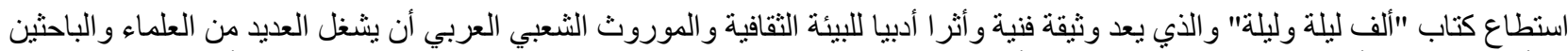

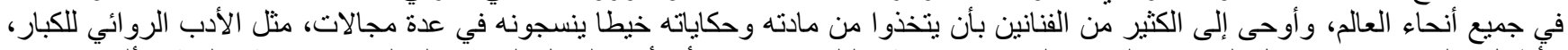

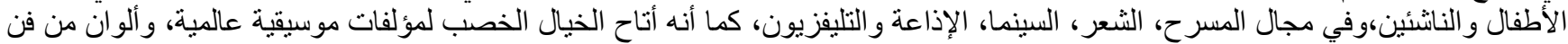

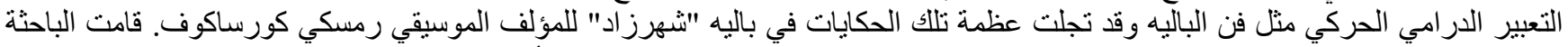

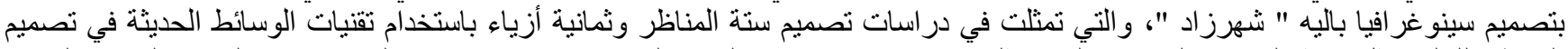

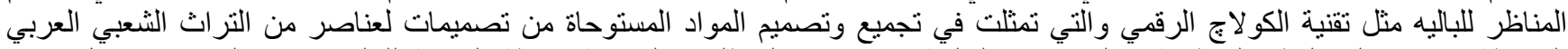

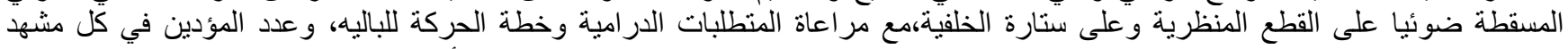

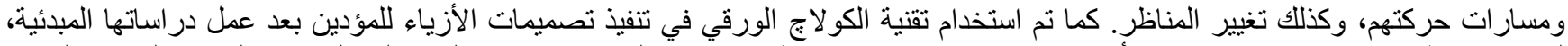

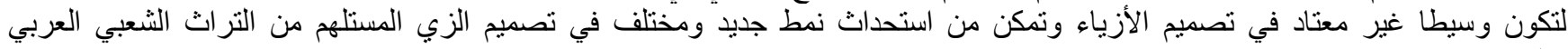
و الفارسي.

الكلمات الدالة: الباليه، سينوغر/فيا، الأزياء، الكولاج، التراث، تصميم الدناظر، الوسائط

\section{1}

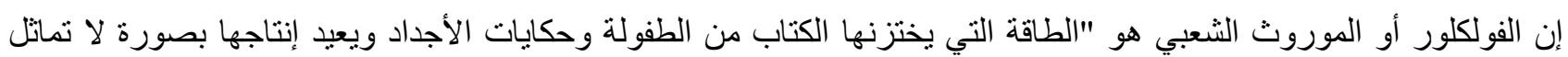

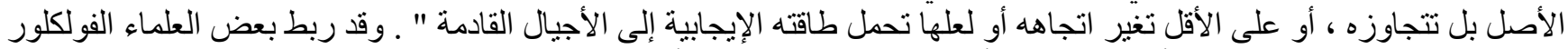

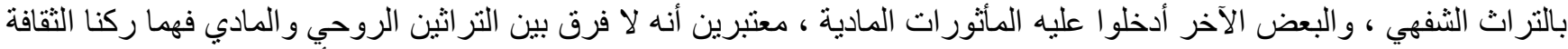

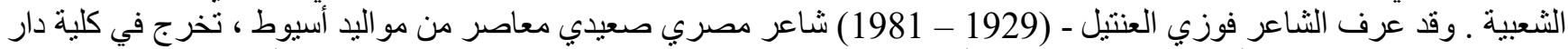
العلوم ودرس الفو لكلور في أيرلندا [1]

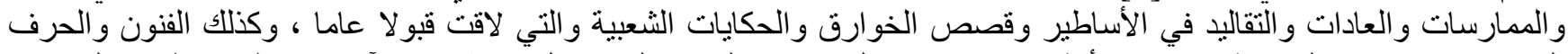

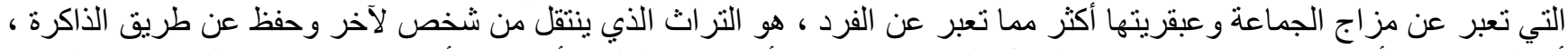

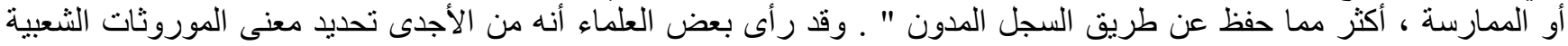

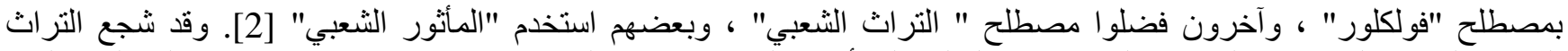

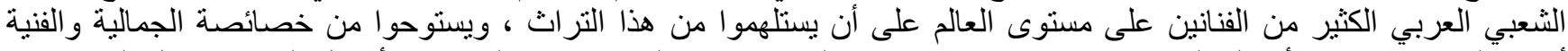
أعمالا ليست بعيدة عن أصالة الماضي ، ولاني علي غريبة عن روح العصر ، هذه المحاو لات شملت جميع أشكال الفنون في كل المجالات ، 
W. S. Author, Paper Title; Vol. 8, R. 2020, Issue No. 1.

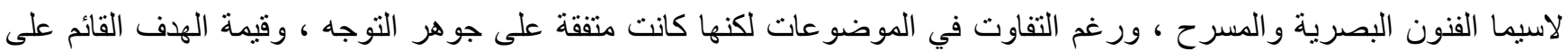

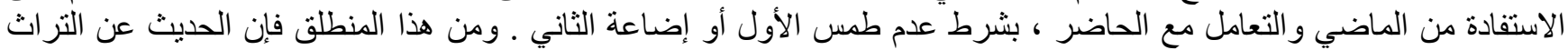

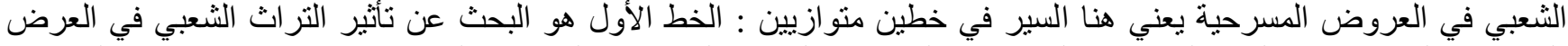

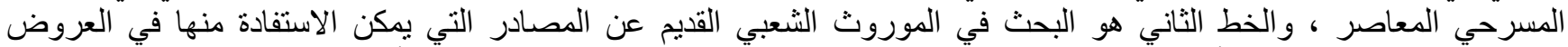

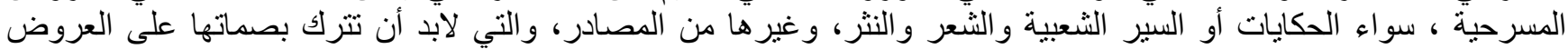

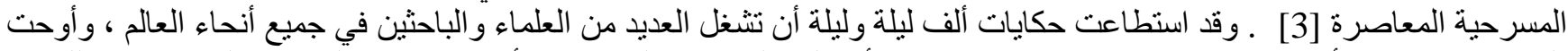

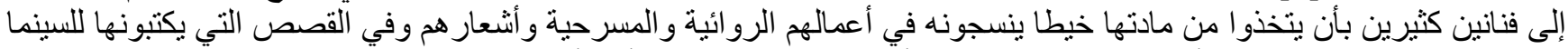

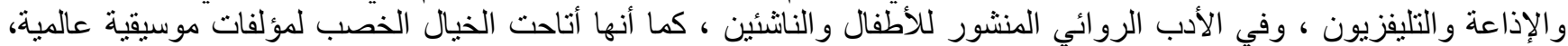

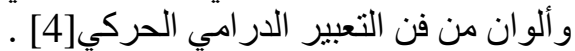

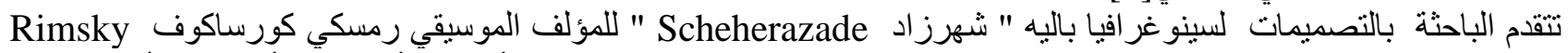
(1908) - 1844) - Korsakov

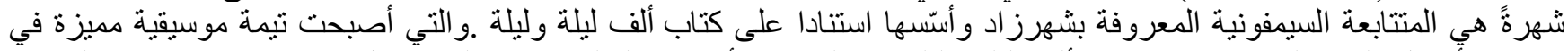

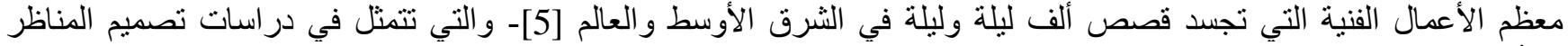

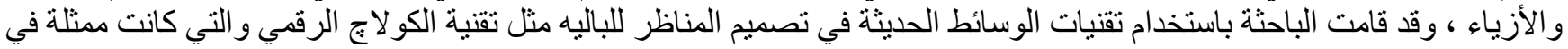

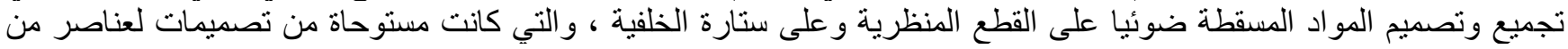

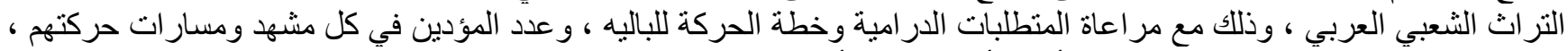

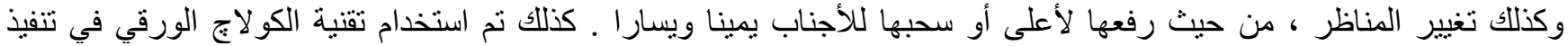
تصميمات الأزياء للمؤدين بعد عمل در اساتها المبدئية ، وذللك لتكون وسيط غئ فير معناد في تصميم الأزياء وتمكن الباحثة من استحداث

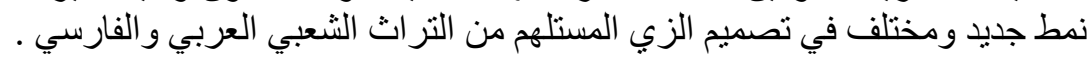

2.

يتكون بالبه شهرزاد من أربعة حركات تدور في بيئات مكانية مختلفة ، والموسيقى كانت عبارة عن متتابعة سيمفونية ألفها رمسكي

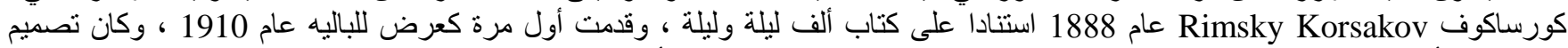

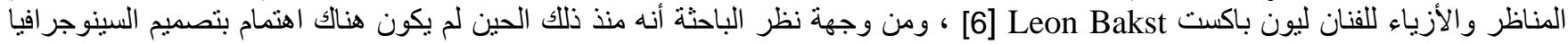

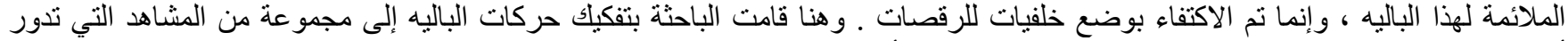

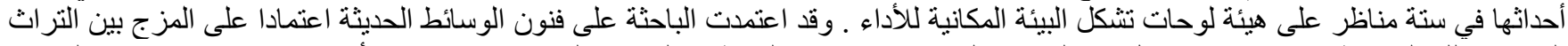

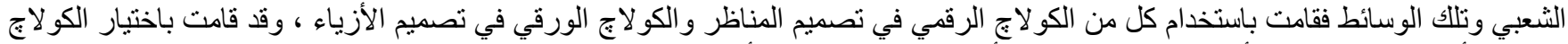

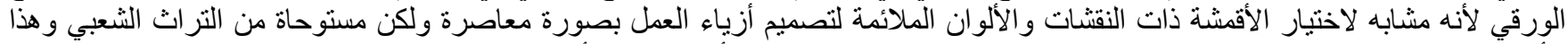

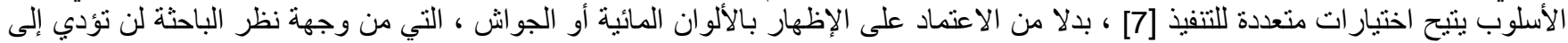

\section{3}

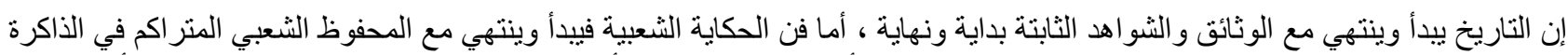

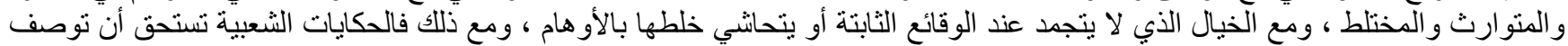

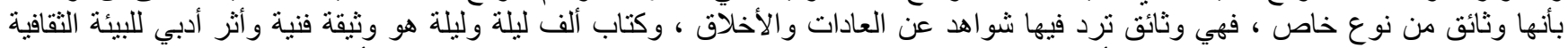

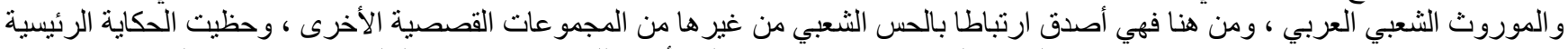

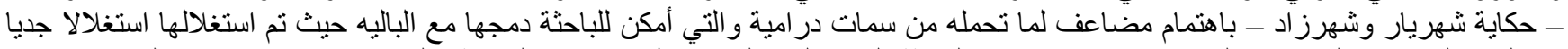

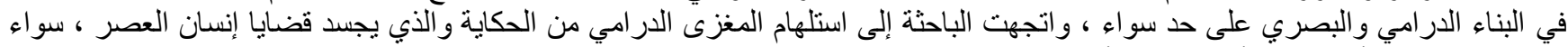

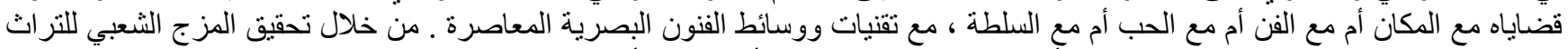

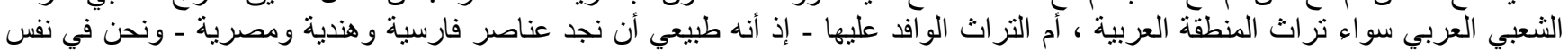

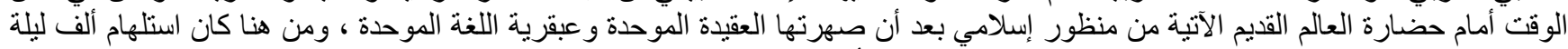

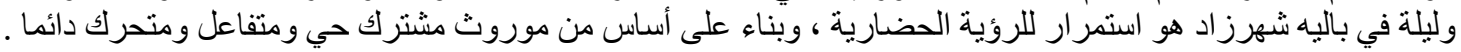

\section{4.}

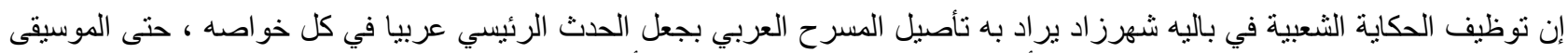

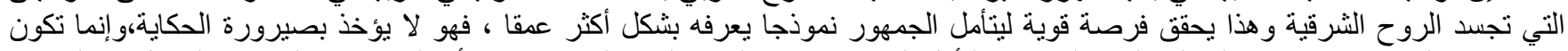

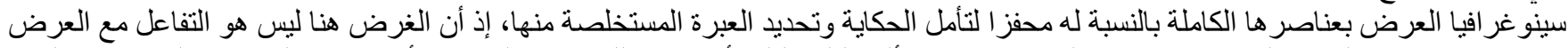

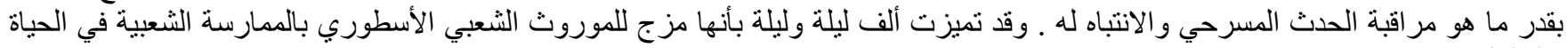




\section{SJFA Scientific Journal of the Faculty of Fine Arts Alexandria University}

تجسيد روح الحكايات الثرقية من خلال المزج بين جماليات الموروث الشعبي العربي مع الوسائط و التقنيات الحديثة مع تتاغم أخاذ في الجمل

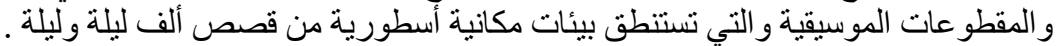

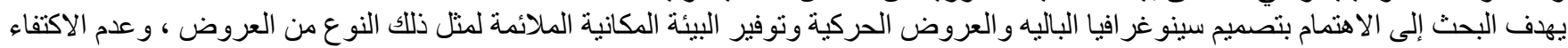

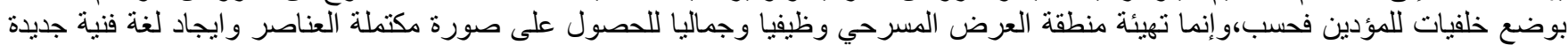

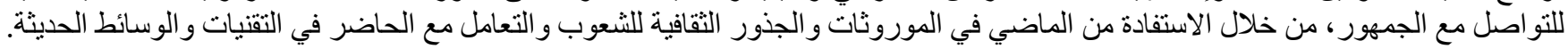

\section{5}

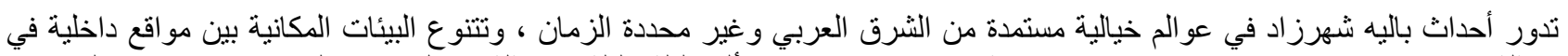

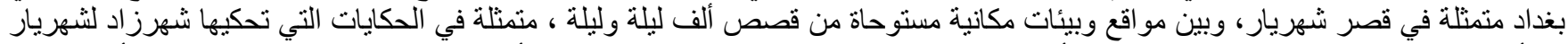

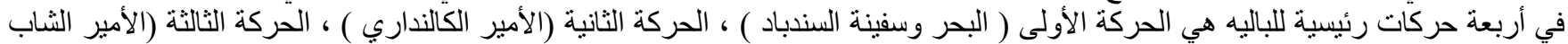

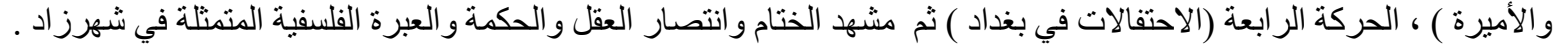

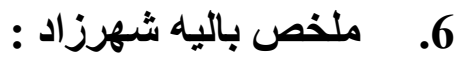

هو من أهم و أثنهر المتتابعات السيمفونية التي ألفها رمسكي كورساكوف Rimsky Korsakov استتادا على كتاب ألف ليلة وليلة ، وتدور

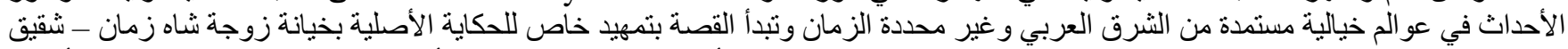

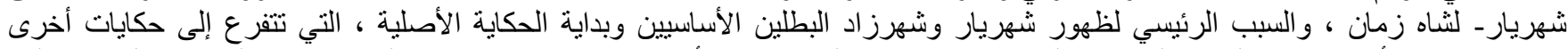

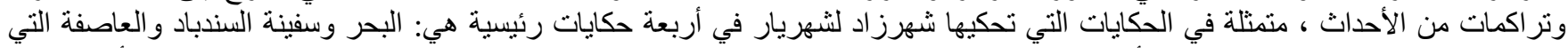

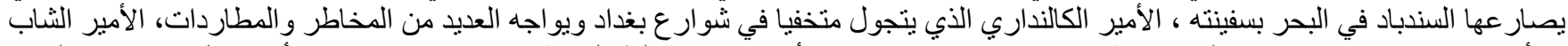

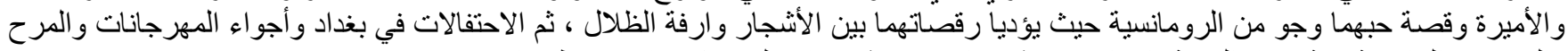

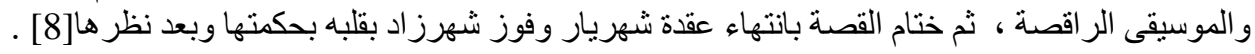

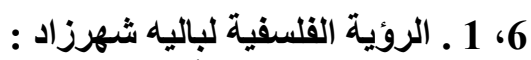

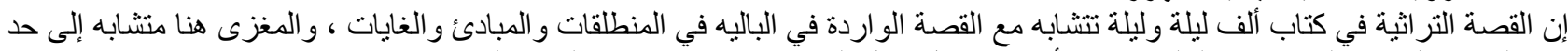

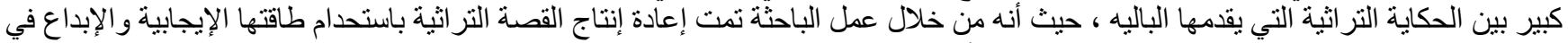

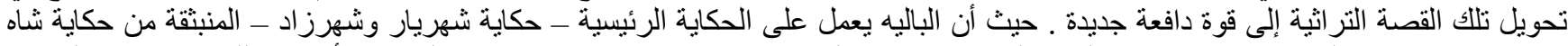

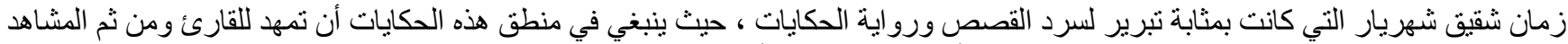

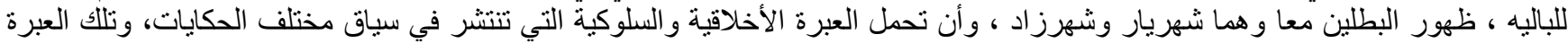

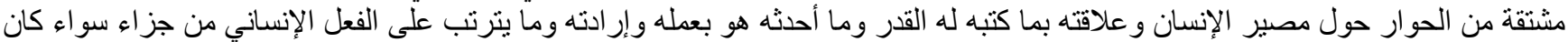

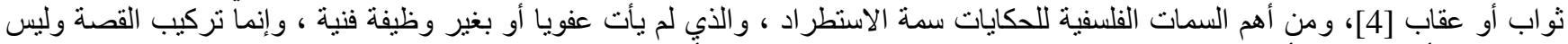

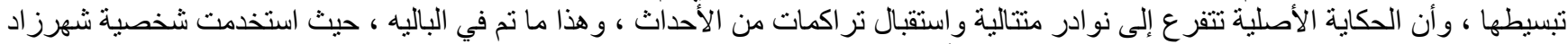

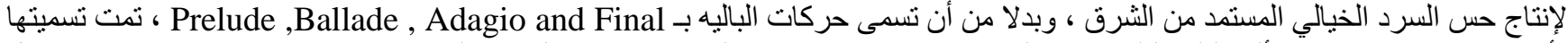
بأسماء مستمدة من حكايات ألف ليلة وليلة ، حتى الختام حيث فازت شهرز اد بقلب شهريار وجعلها في النهاية تحظى بنوم هانئ بدلا من توترها كل

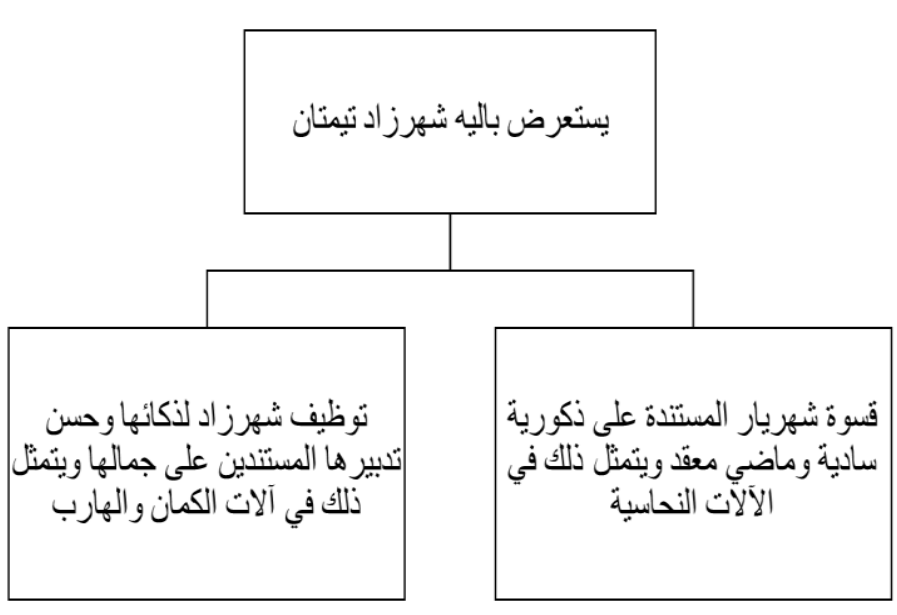


W. S. Author, Paper Title; Vol. 8, R. 2020, Issue No. 1.

ينكون باليه شهرز اد من أربعة حركات ، قامت الباحثة بإضافة تمهيد للحركة الأولى وهي حكاية شاه زمان شقيق شهريار و التي هي بمثابة تبرير

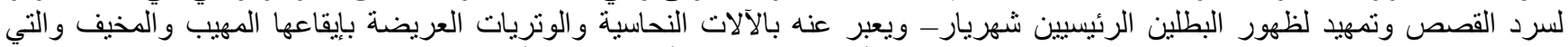

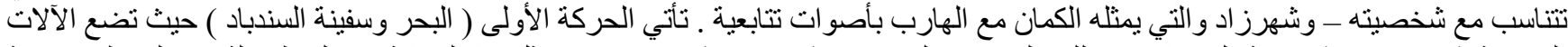

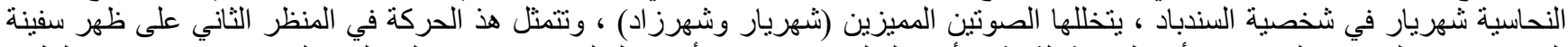

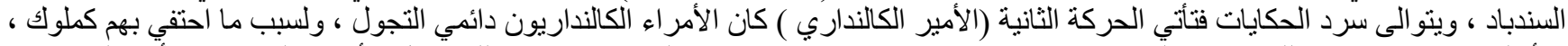

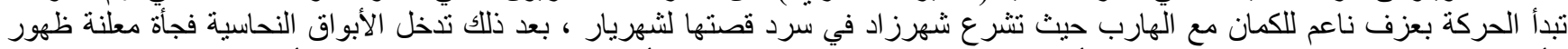

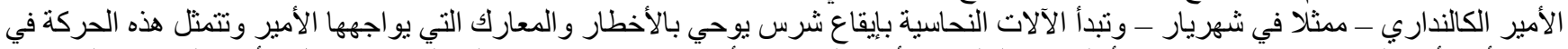

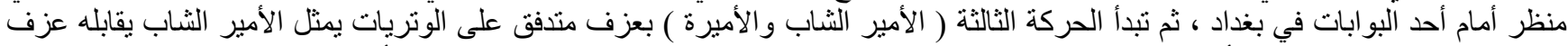

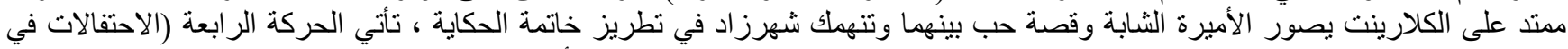

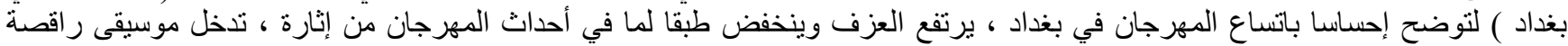

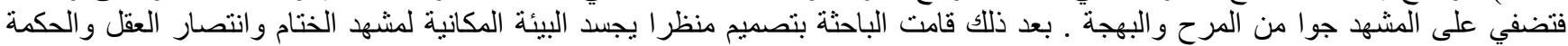

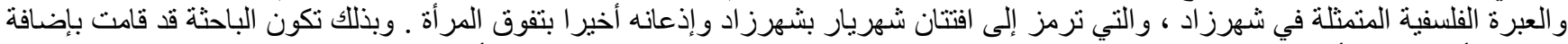

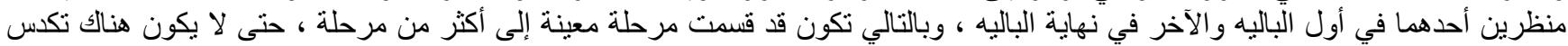

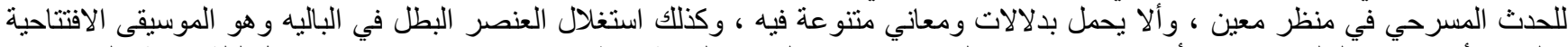

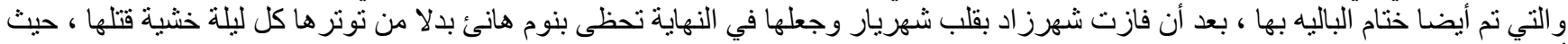

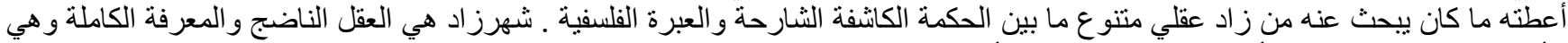
الأداة التي تستعرض شان شتى الأخبار و السير ومختلف منت الأقو ال و الحكم .

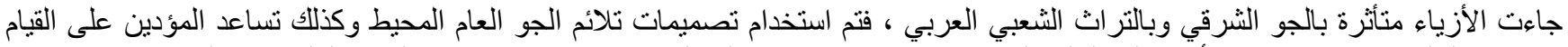

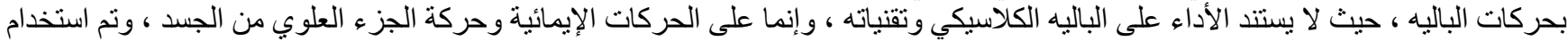

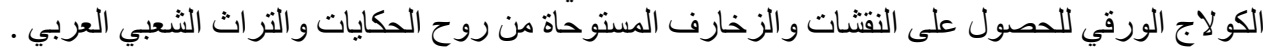

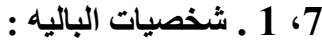

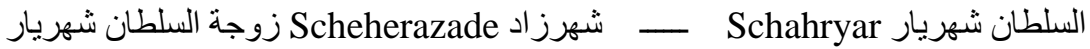

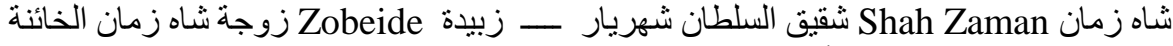

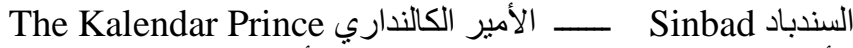

The young Princess الأمير الثاب The Young Prince الأميرة الثنابة The The

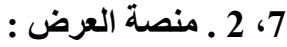

افترضت الباحثة أن العرض يقام على خشبة مسرح بروسينيوم ذات أبعاد 14 م عرض x 10 م عمق وفتحة البروسينيوم ارتفاعها 8 م .

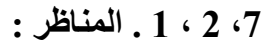

قامت الباحثة بعمل الكروكيات المبدئية للمناظر و التي تم تطوير ها للوصول إلى التصميم النهائي لكل منظر ـ وقد مر تصميم المناظر بعدة مراحل :

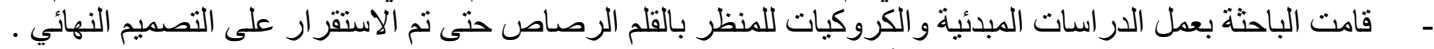

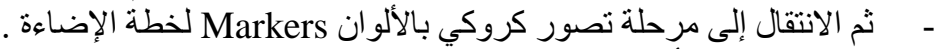

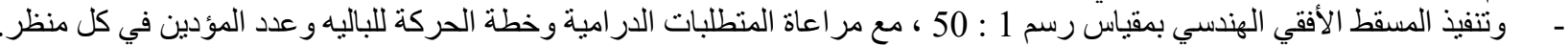
- - مثم المرحلة الأخيرة وهى التنفيذ الرقمي ببرنامج 3D Max، لإظهار التصميم بشكل ثلاثي الأبعاد في صورته النهائية بالإضـاءة و الخامات.

\section{المنظر الأول : منظر داخل قصر شهريار}

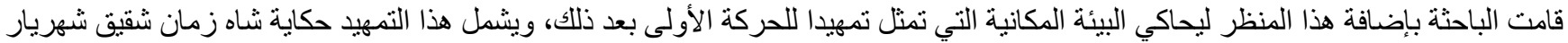

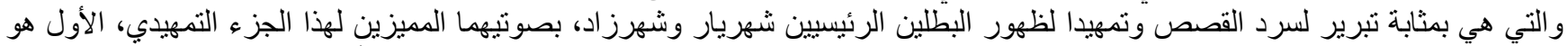

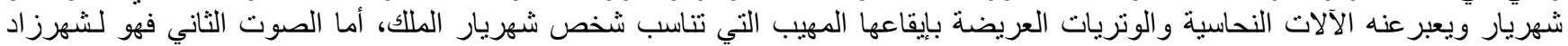

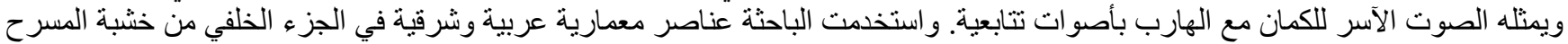

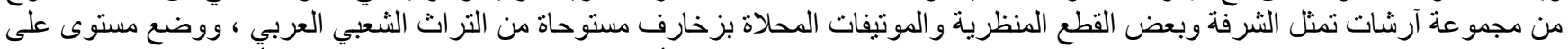

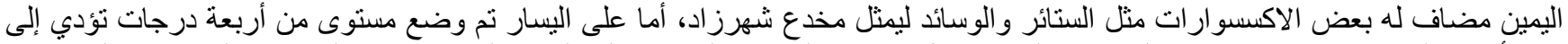

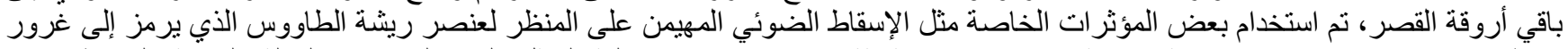

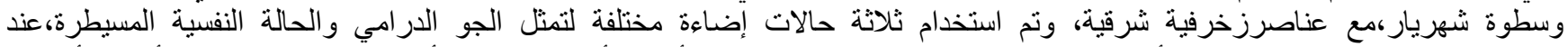

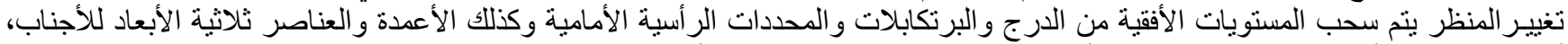

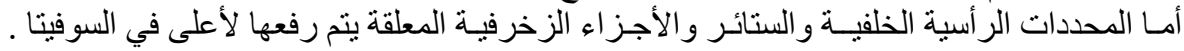




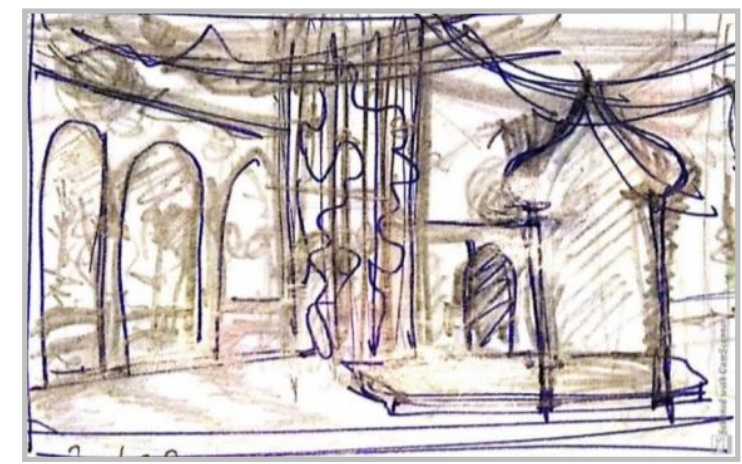

شكل 2: در اسة أولية من تصميم الباحثة للمنظر الأول داخل قصر شهريار

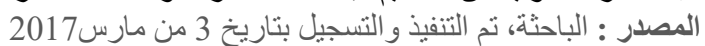

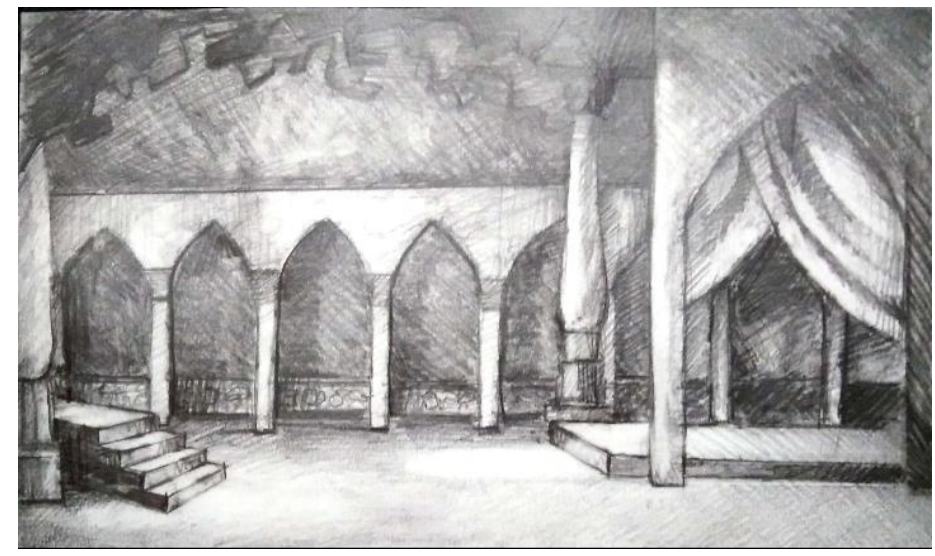

شكل 3: در اسة بالقلم الرصاص من تصميم الباحثة للمنظر الأول داخل قصر

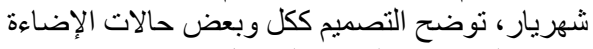

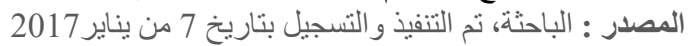
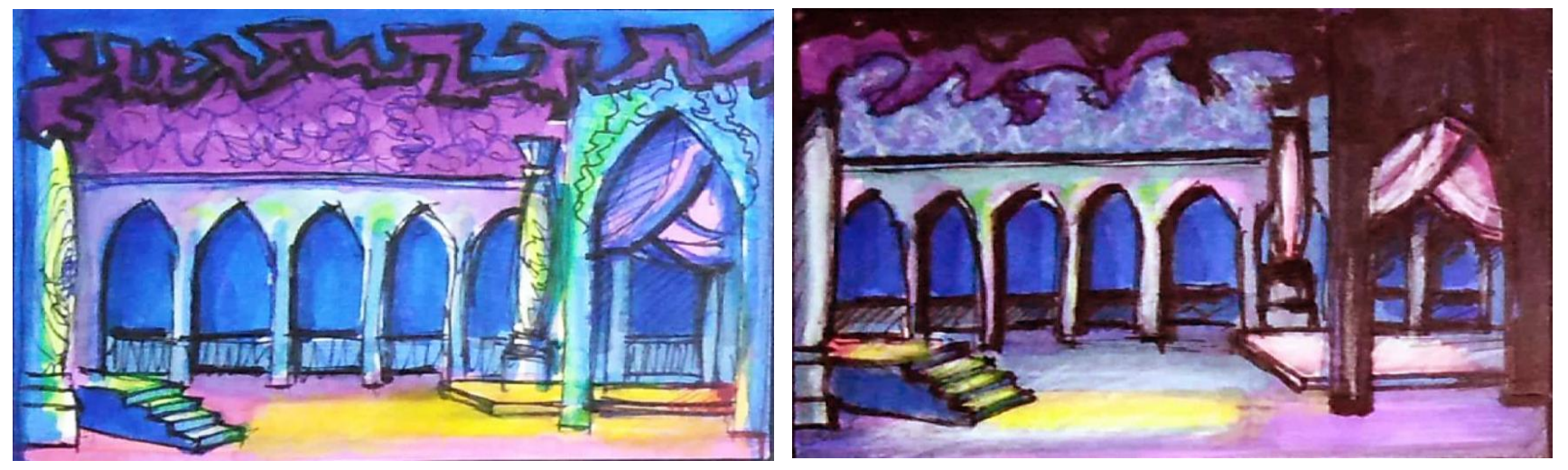

شكل 4: در اسات بالألوان Markers من تصميم الباحثة للمنظر الأول داخل

قصر شهريار ، توضح التصميم ككل وبعض حالات الات الإضـاءة

المصدر : الباحثة، ثم التنفيذ و التسجيل بتاريخ 7 من يناير 2017 
W. S. Author, Paper Title; Vol. 8, R. 2020, Issue No. 1.

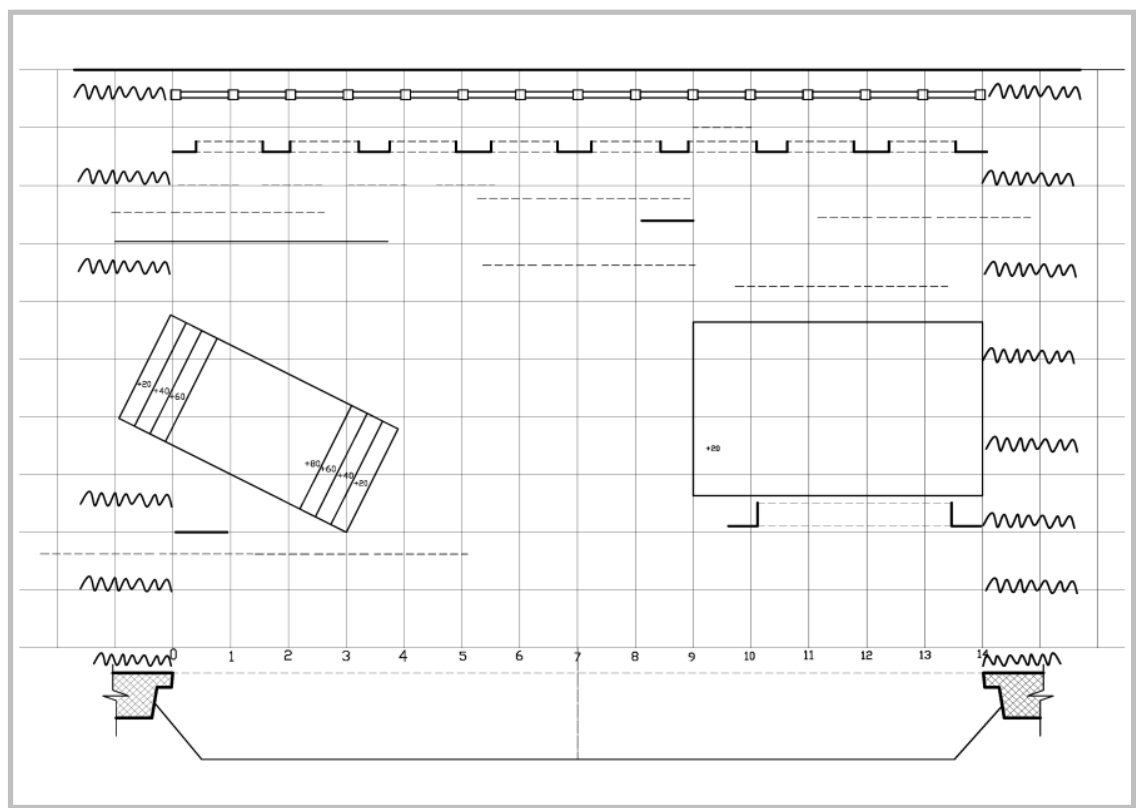

شكل 5: المسقط الأفقي الهندسي للمنظر الأول داخل قصر شهريار

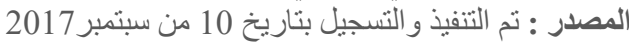

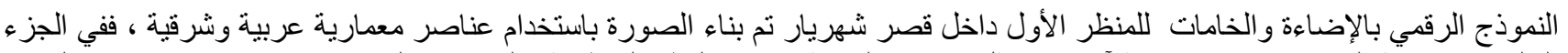

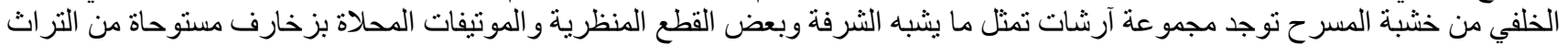

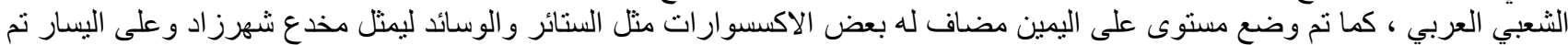

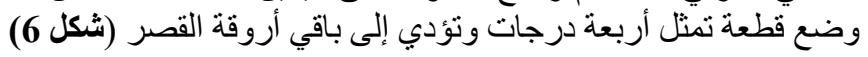

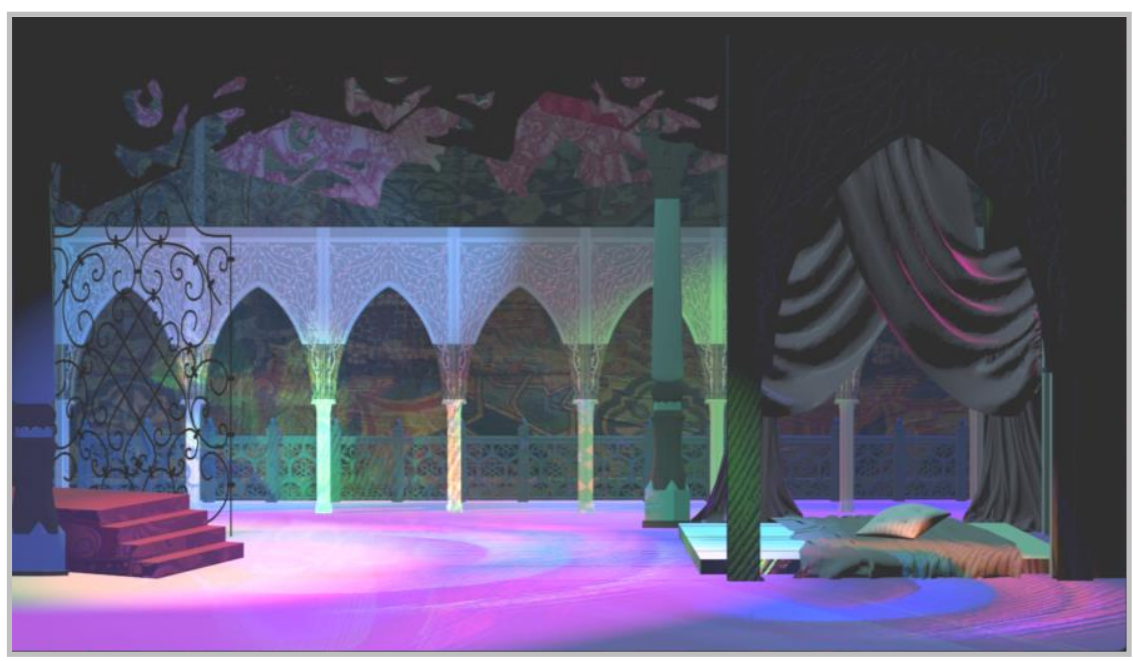

شكل 6: النموذج الرقمي للمنظر الأول داخل قصر شهريار

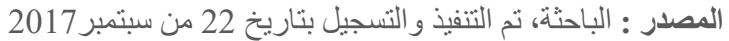

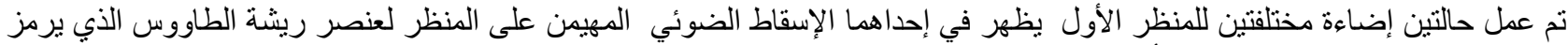

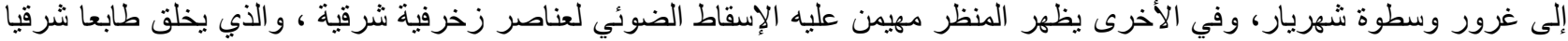
وأجو اء أسطورية (شكل 7) 


\section{SJFA}

Scientific Journal of the Faculty of Fine Arts Alexandria University
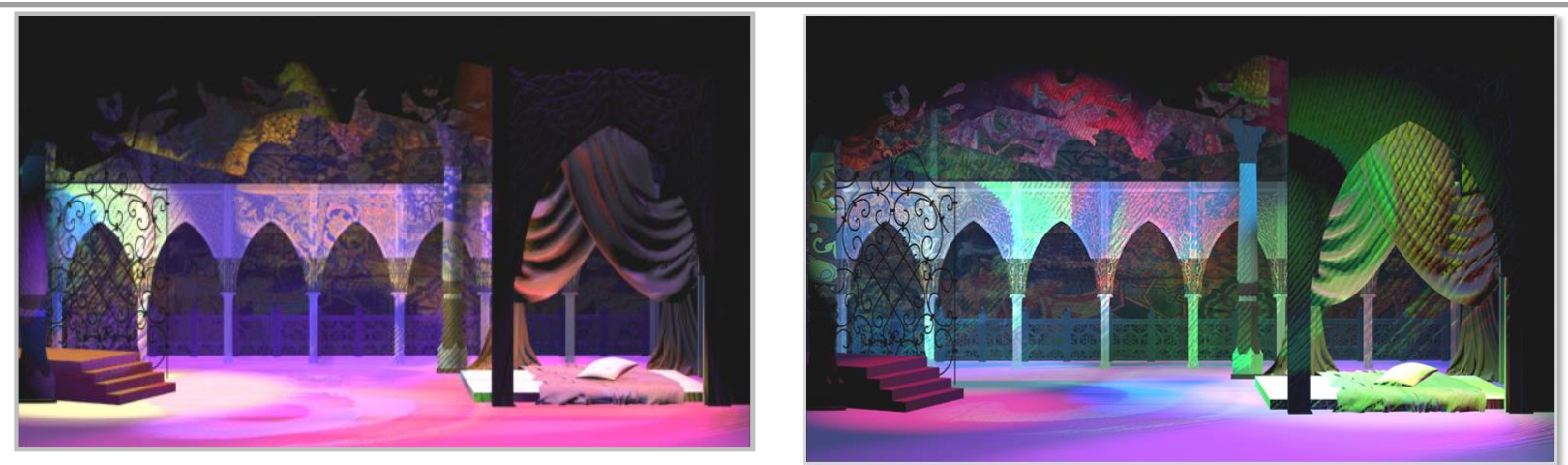

شكل 7: النموذج الرقمي للمنظر الأول داخل قصر شهريار في حالتين إضـاءة مختلفتين

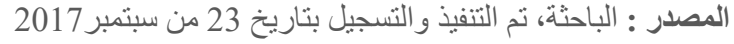

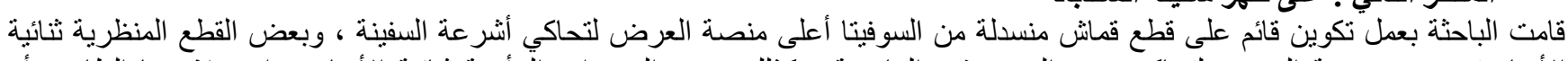

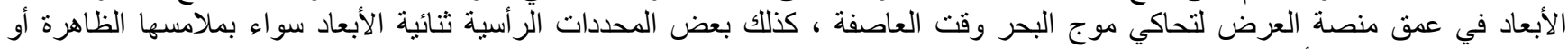

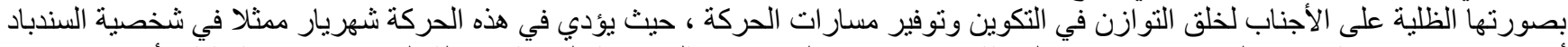

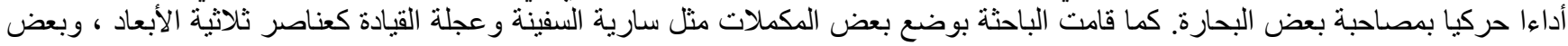

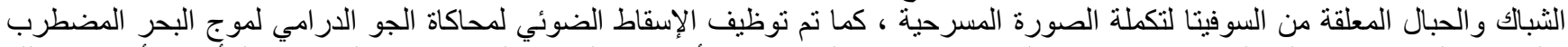

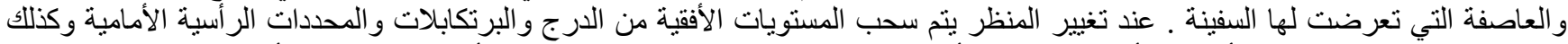
سارية السفينة وعجلة القيادة للأجناب ، أما المحددات الر أسية الخلفية وقطع القماث المعلقة المحاكية للأشرعة يتم رفعها لأعلى في السوفيتا .

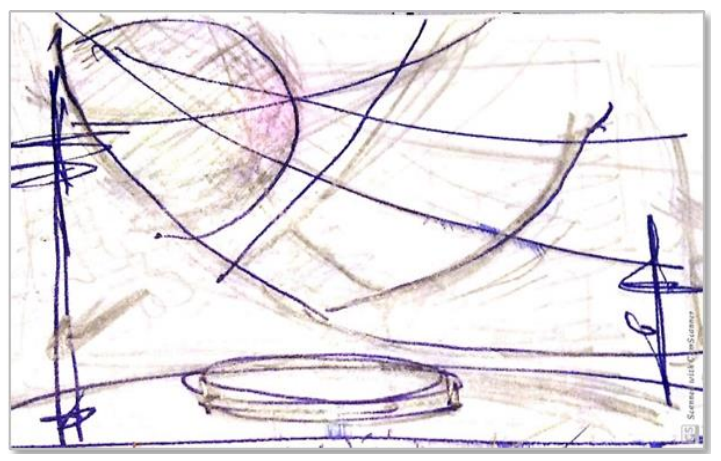

شكل 8: دراسة أولية من تصميم الباحثة للمنظر الثاني على ظهر سفينة السندباد

المصدر : الباحثة، تم التنفيذ و التسجيل بتاريخ 3 من مارس 2017

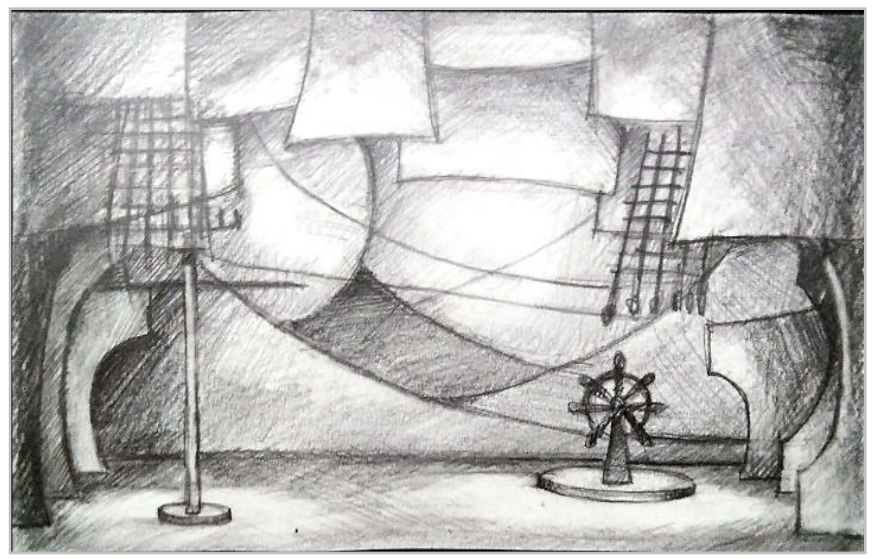

$$
\begin{aligned}
& \text { شكل 9: در اسة بالقلم الرصاص تصميم الباحثة للمنظر الثاني على ظهر سفينة }
\end{aligned}
$$

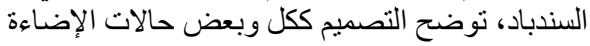


W. S. Author, Paper Title; Vol. 8, R. 2020, Issue No. 1.
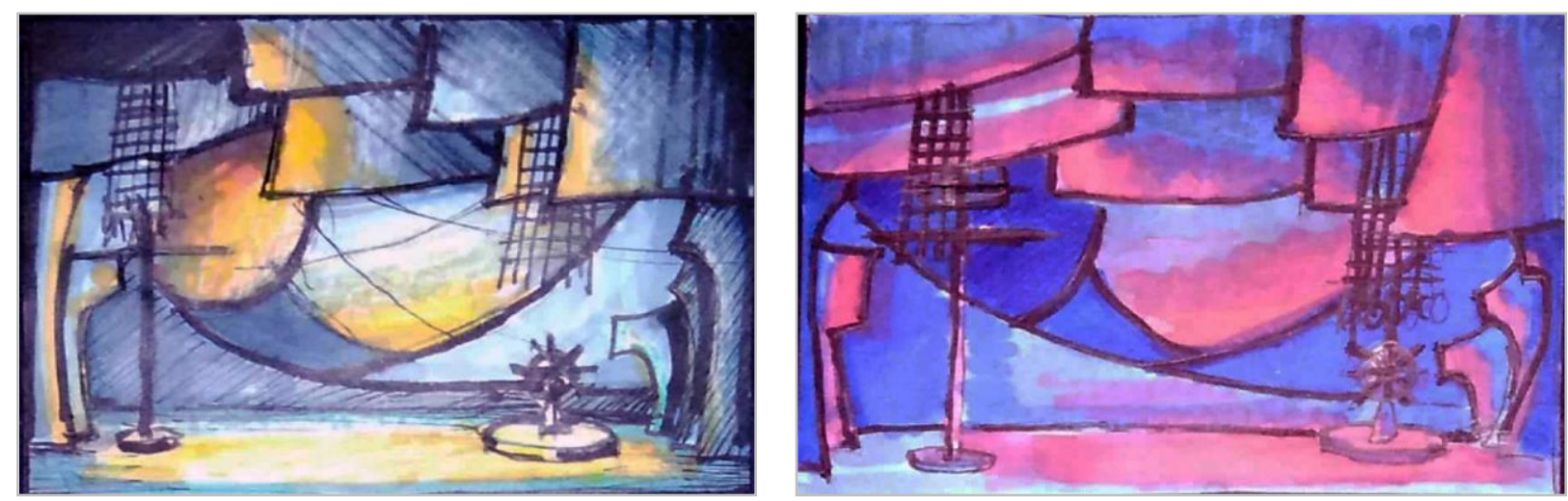

شكل 10: دراسات بالألوان Markers تصميم الباحثة للمنظر الثاني على ظهر

سفينة السندباد، توضح التصميم ككل وبعض حان الات التات الإضاءة

المصدر : الباحثة، تم التنفيذ و التسجيل بتاريخ 7 من من بناير الإضياءة 2017

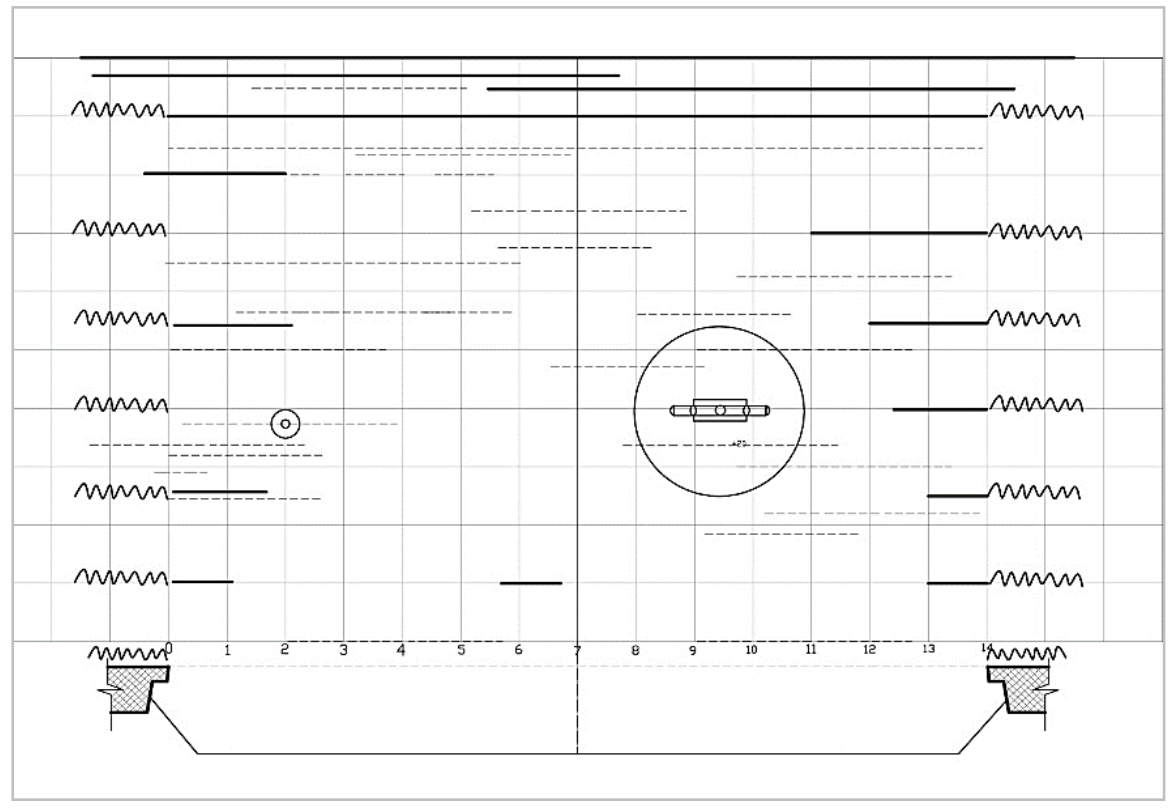

شكل 11: المسقط الأفقي الهندسي للمنظر الثاني على ظهر سفينة السندباد

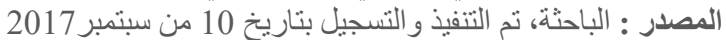

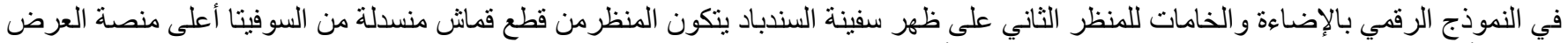

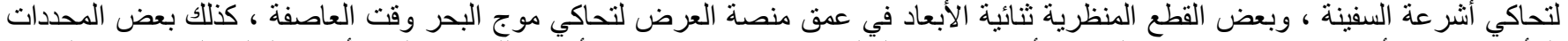

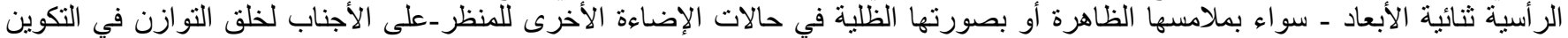

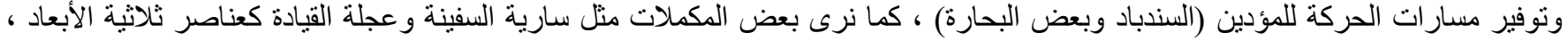

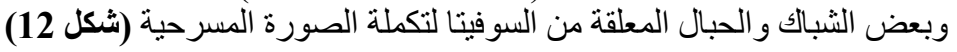




\section{SJFA}

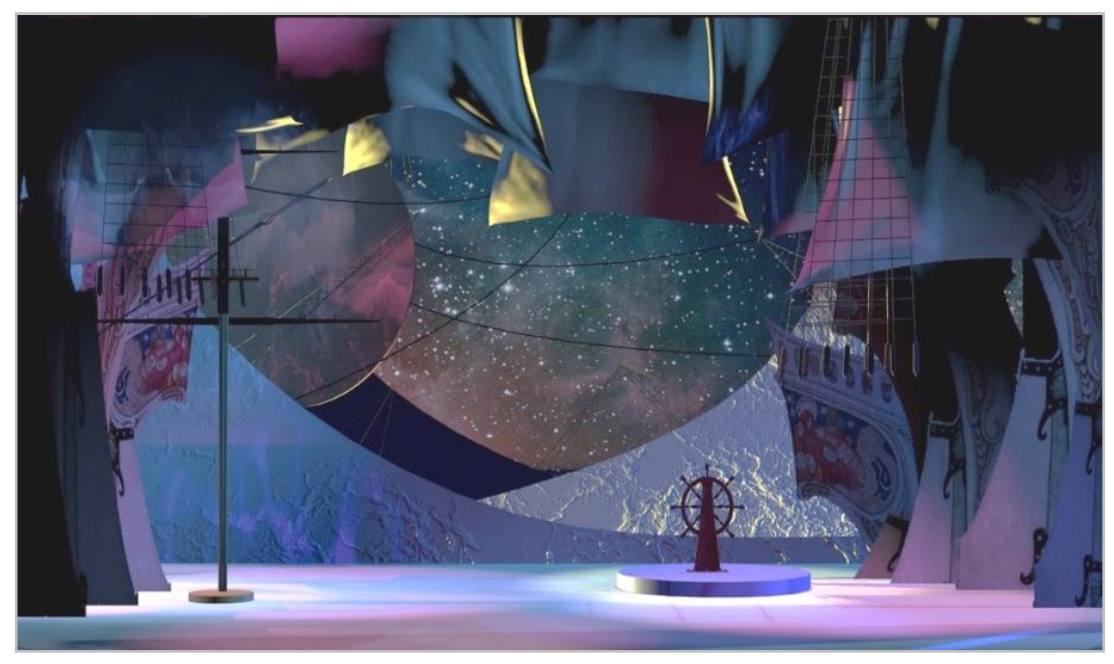

شكل 12: النموذج الرقمي للمنظر الثاني على ظهر سفينة السندباد

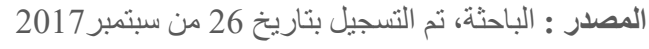

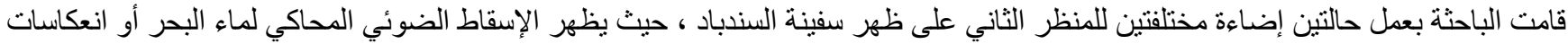
الضوء على الماء المهيمن على المنظر لخلق الجو العام لموج البحر المضطرب و العاصفة التي تعرضت لها السفينة (شكل 13)
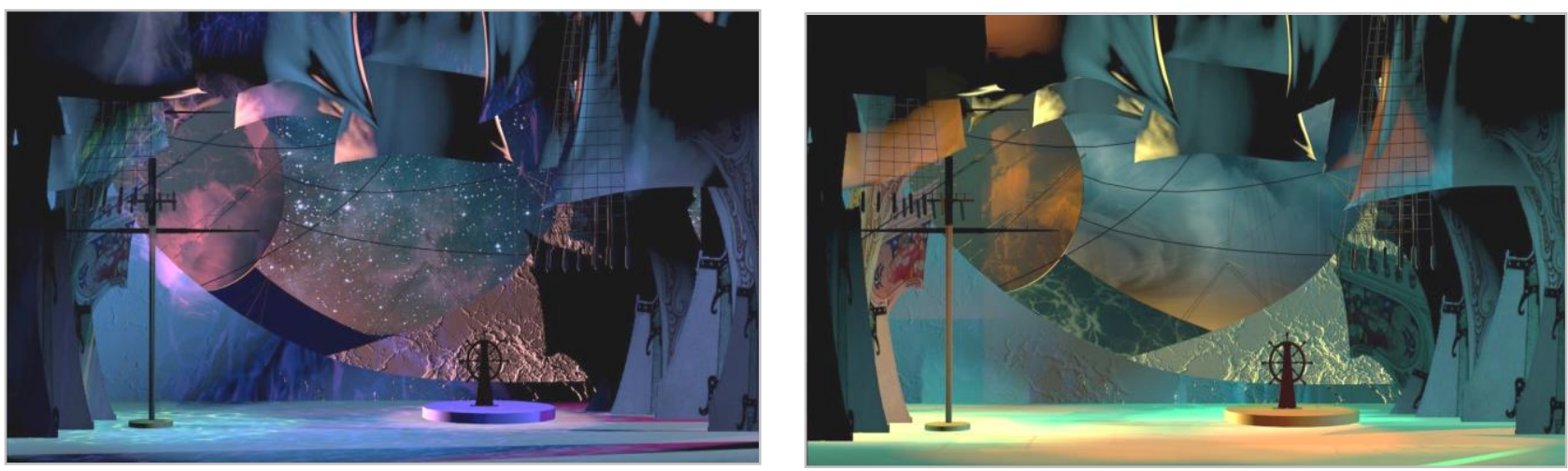

شكل 13: النموذج الرقمي للمنظر الثاني على ظهر سفينة السندباد في حالتين إضاءة مختلفتين

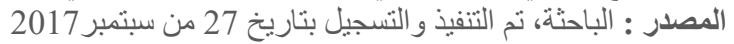

\section{المنظر الثالث : الأمير الكالنداري}

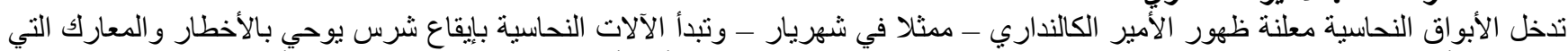

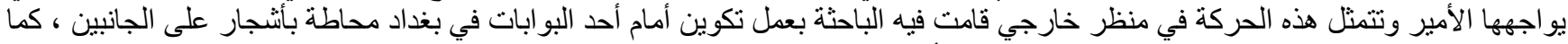

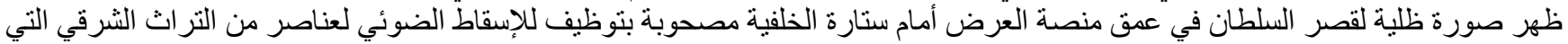

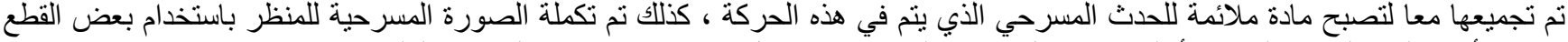

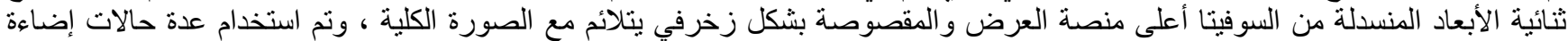

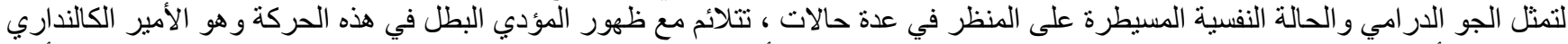

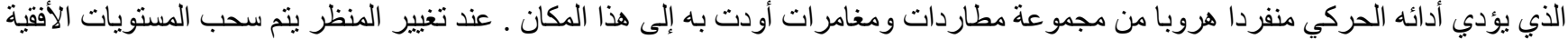

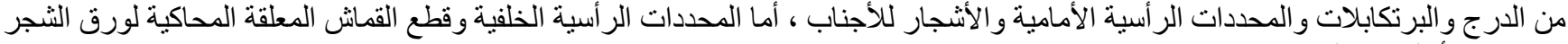


W. S. Author, Paper Title; Vol. 8, R. 2020, Issue No. 1.

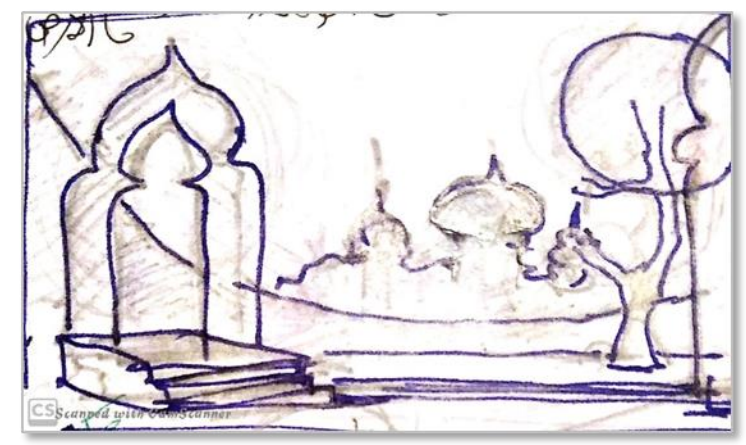

شكل 14: دراسة أولية من تصميم الباحثة للمنظر الثالث الأمير الكالنداري

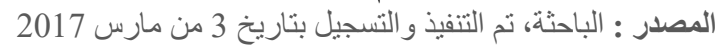

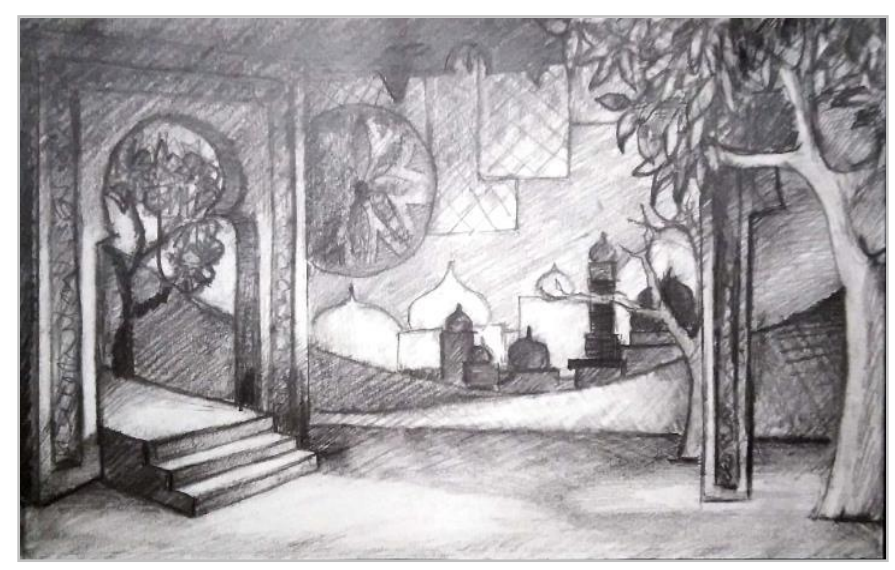

$$
\begin{aligned}
& \text { شكل 15: دراسة بالقلم الرصاص للمنظر الثالث الأمير الكالنداري، توضح }
\end{aligned}
$$

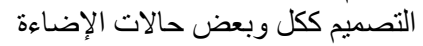

$$
\begin{aligned}
& \text { المصدر : الباحثة، تم التنفيذ و التسجيل بتاريخ } 8 \text { من يناير } 2017
\end{aligned}
$$
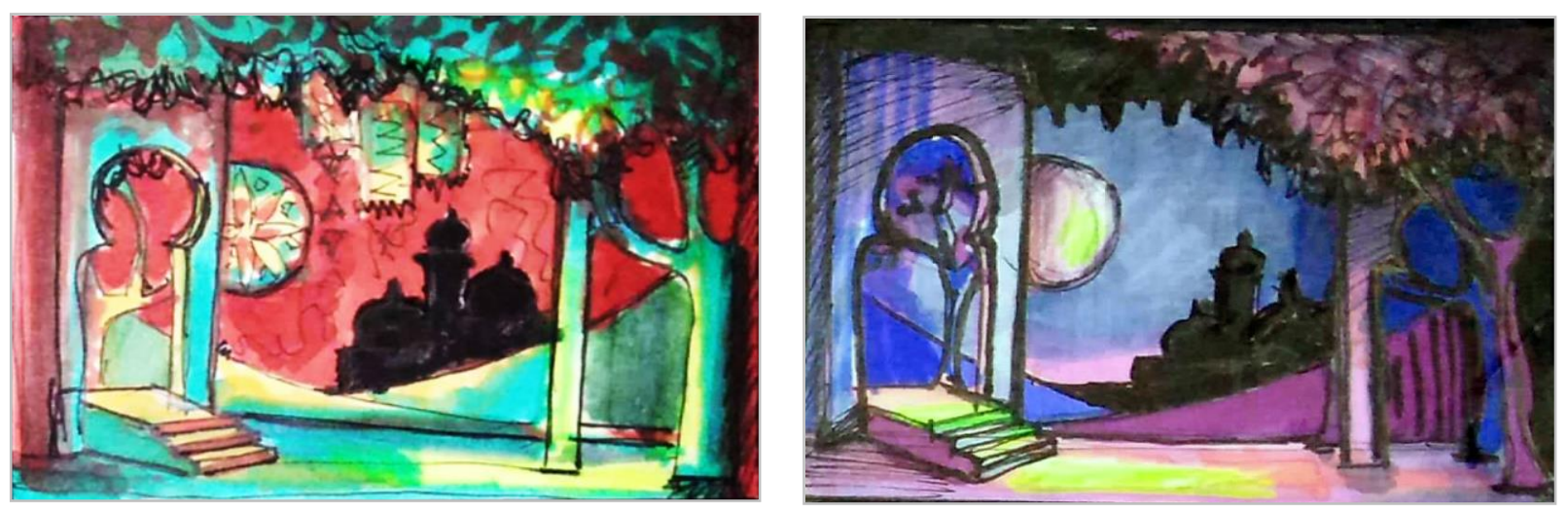

$$
\begin{aligned}
& \text { شكل 16: دراسات بالألوان Markers للمنظر الثالث الأمير الكالنداري، توضح } \\
& \text { التصميم ككل وبعض حالات الإضاءة الإن الإن } \\
& \text { المصدر : الباحثة، نم التنفيذ و التسجيل بتاريخ } 8 \text { من يناير } 2017
\end{aligned}
$$




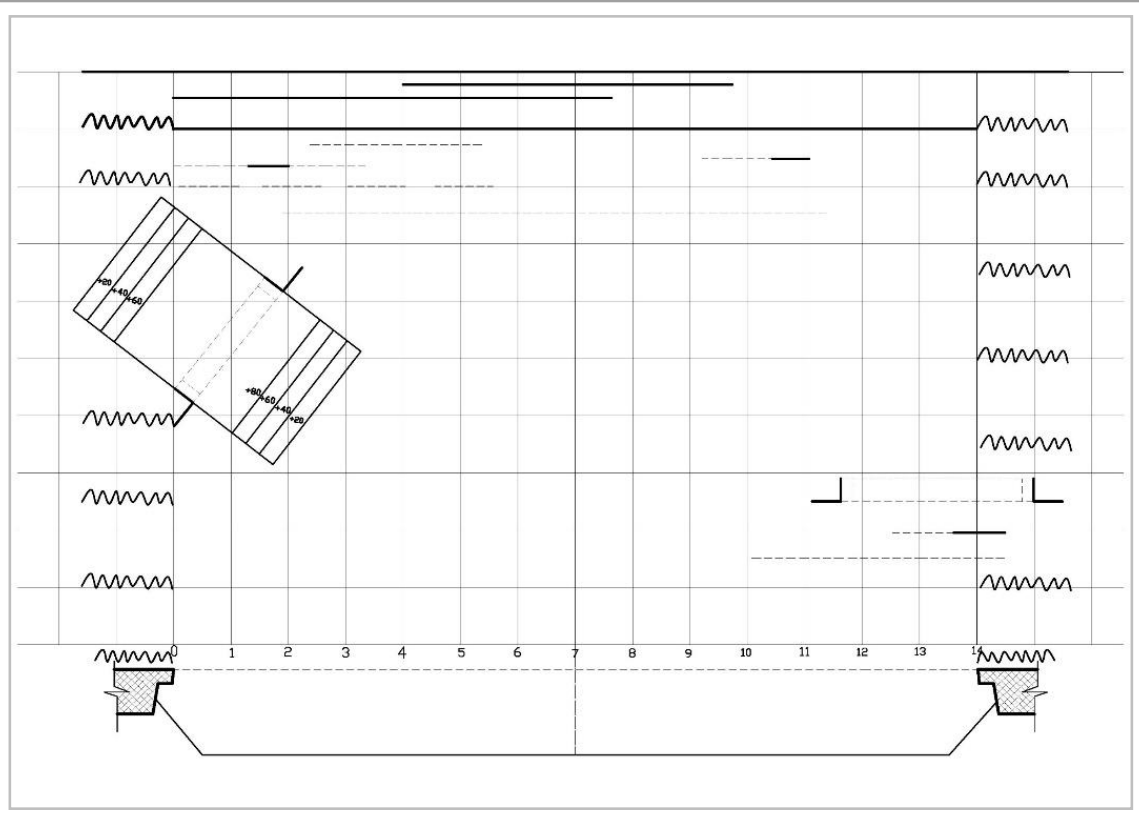

شكل 17: المسقط الأفقي الهندسي للمنظر الثالث الأمير الكالنداري

المصدر : الباحثة، تم التنتفيذ والتنسيل بتاريخ 10 من سبتمبر الأنير الكير 2017

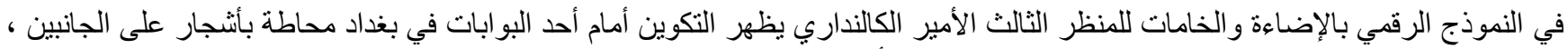

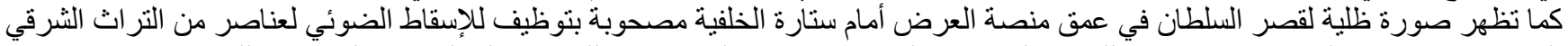

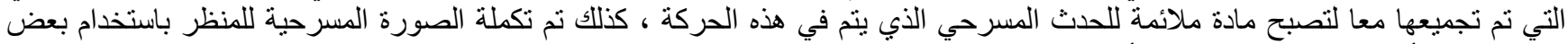

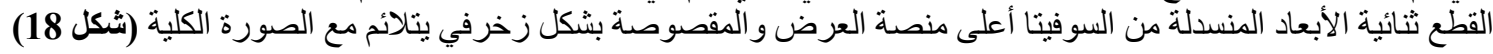

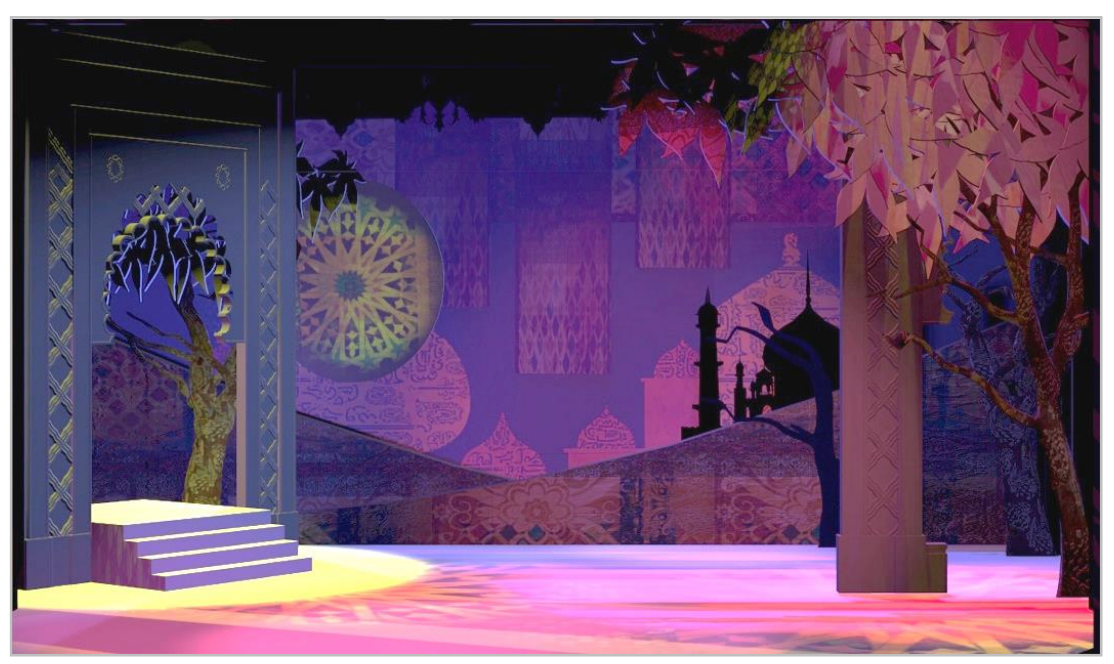

شكل 18: النموذج الرقمي للمنظر الثالث الأمير الكالنداري

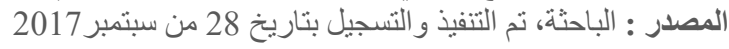

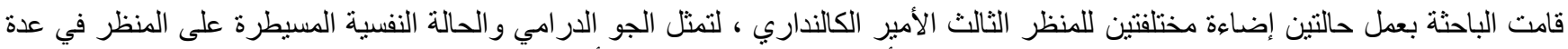

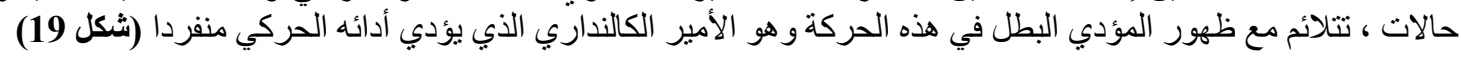


W. S. Author, Paper Title; Vol. 8, R. 2020, Issue No. 1.
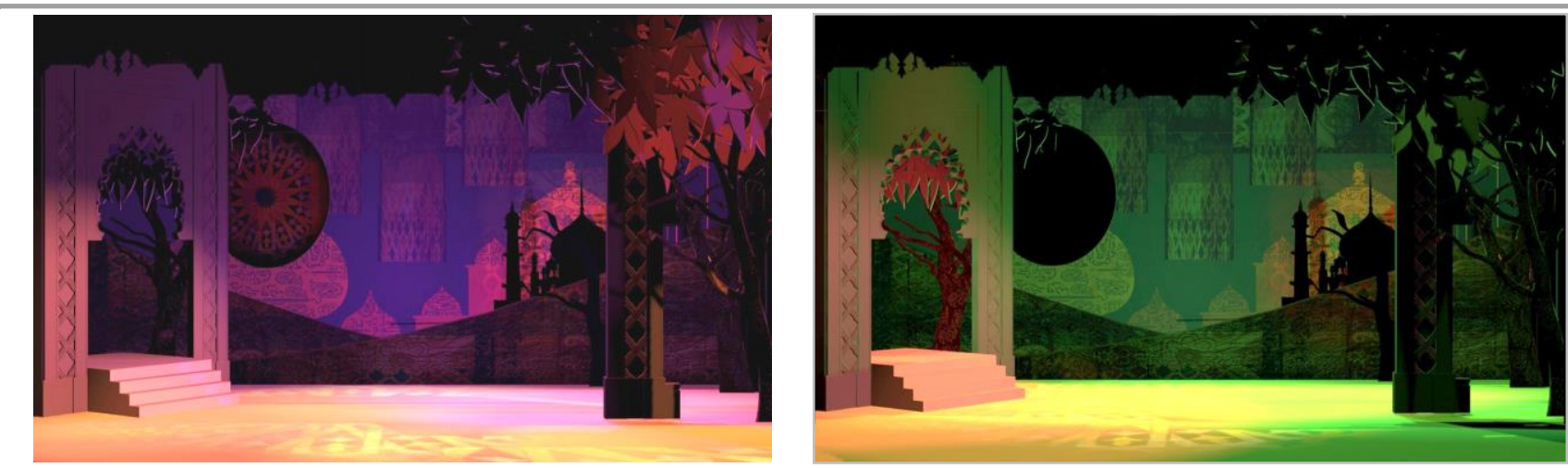

شكل 19: النموذج الرقمي للمنظر الثالث الأمير الكالنداري في حالتين إضـاءة مختلفتين

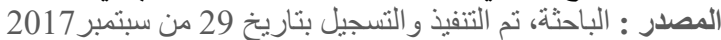

المنظر الرابع : الأمير الثاب والأميرة الثابة

تبدأ الحركة الثالثة ( الأمير الثاب والأميرة ) في هذا المنظر بعزف متدفئق على الوتريات يمثل الأمير الثاب يقابله عزف ممتد على الكلارينت

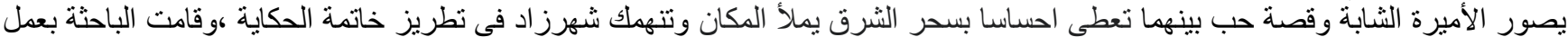

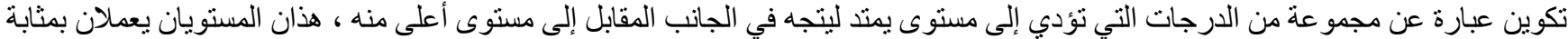

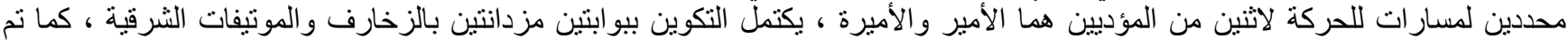

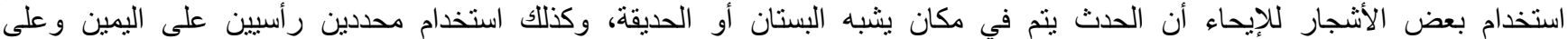

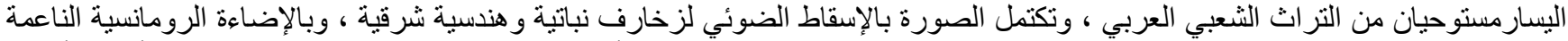

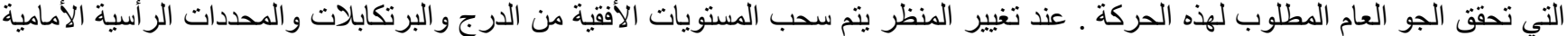

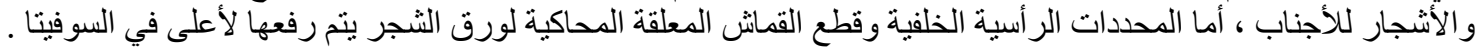

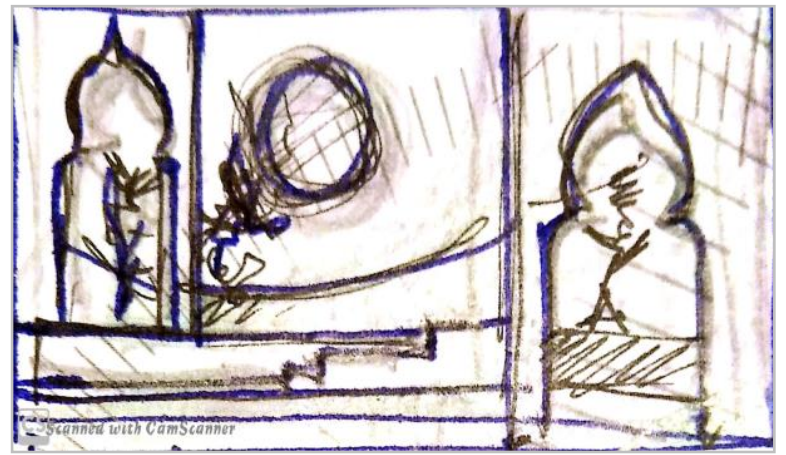

شكل 20: دراسة أولية من تصميم الباحثة للمنظر الرابع الأمير الثاب و الأميرة الثابة

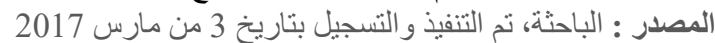

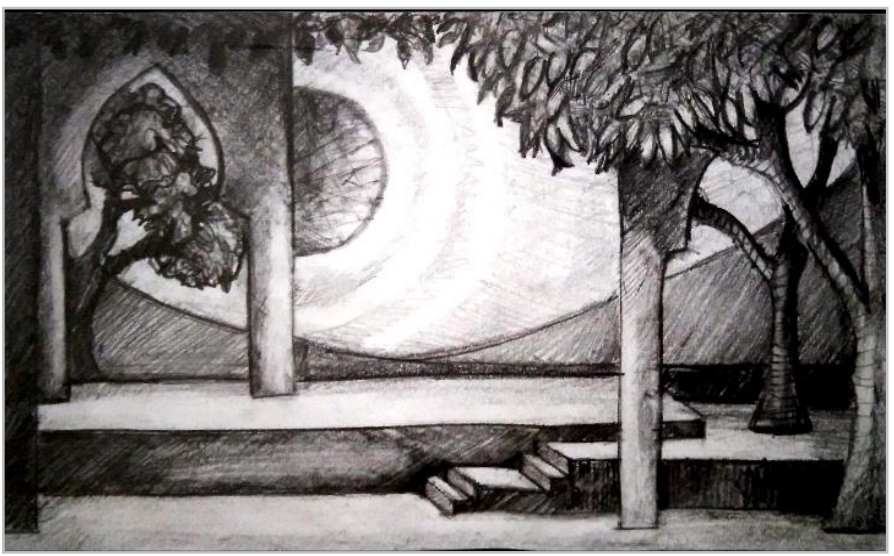

شكل 21: در اسة بالقلم الرصاص تصميم الباحثة للمنظر الر ابع الأمير الثاب

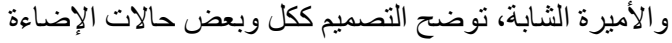
المصدر : الباحثة، تم التسجيل بتاريخ 8 من بناير 2017 


\section{SJFA Scientific Journal of the Faculty of Fine Arts Alexandria University}
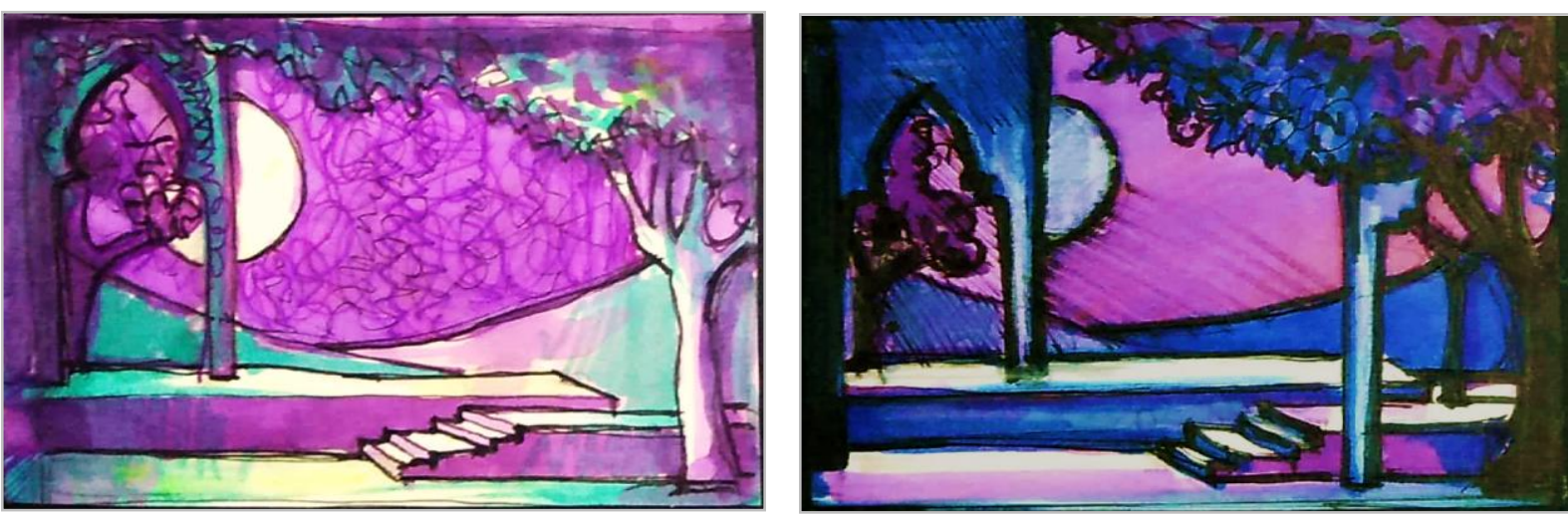

شكل 22: در اسات بالألوان Markers تصميم الباحثة للمنظر الرابع الأمير الثاب

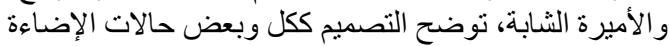

المصدر : الباحثنة، تم التسجيل بثاريخ 8 من بيناير 2017

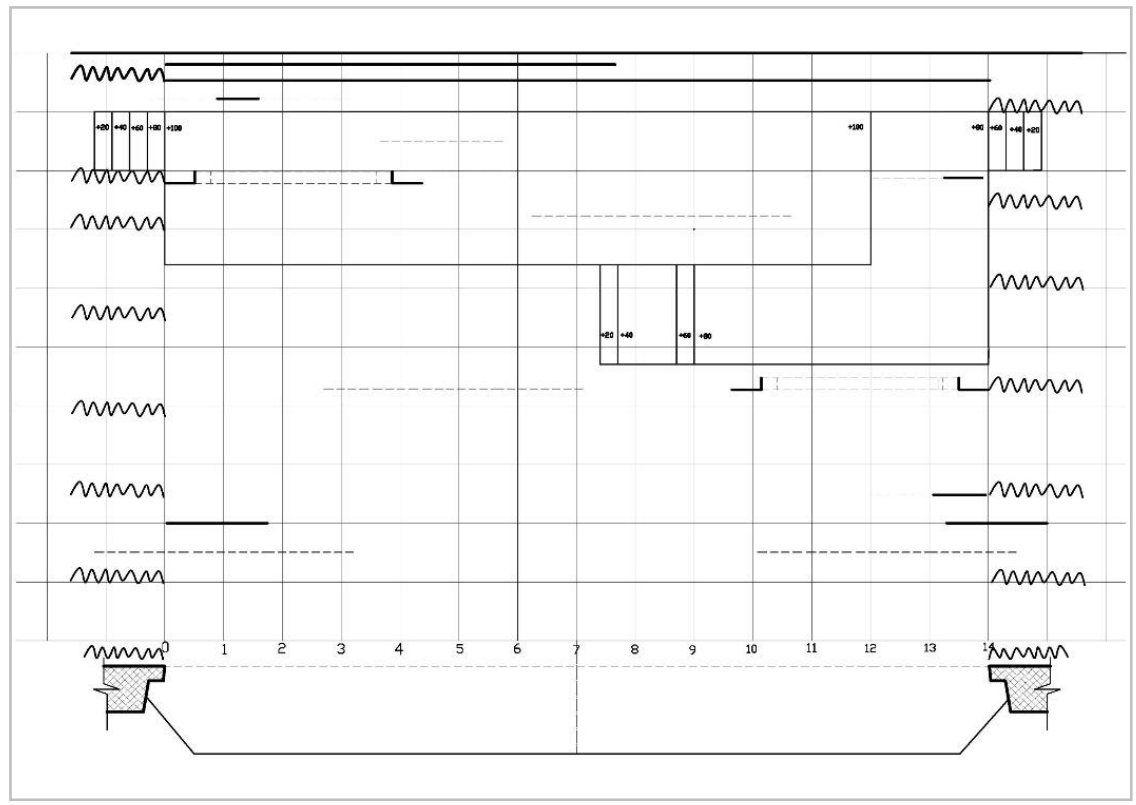

شكل 23: المسقط الأفقي الهندسي للمنظر الثالث الأمير الكالنداري

المصدر : الباحثة، ثم التشجيل بتاريخ 11 من سبتمبر 2017

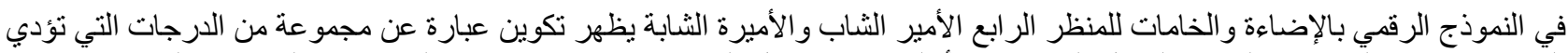

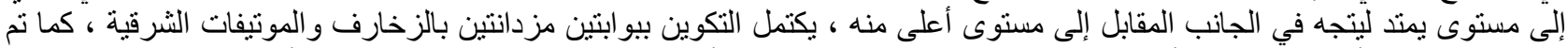

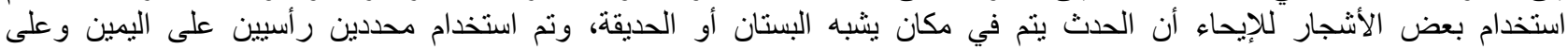

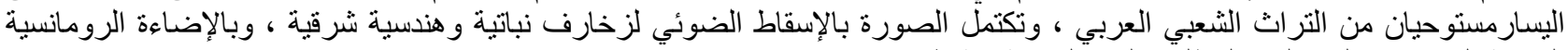

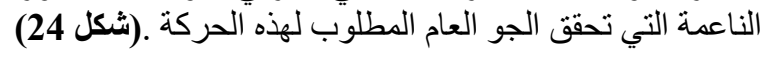


W. S. Author, Paper Title; Vol. 8, R. 2020, Issue No. 1.

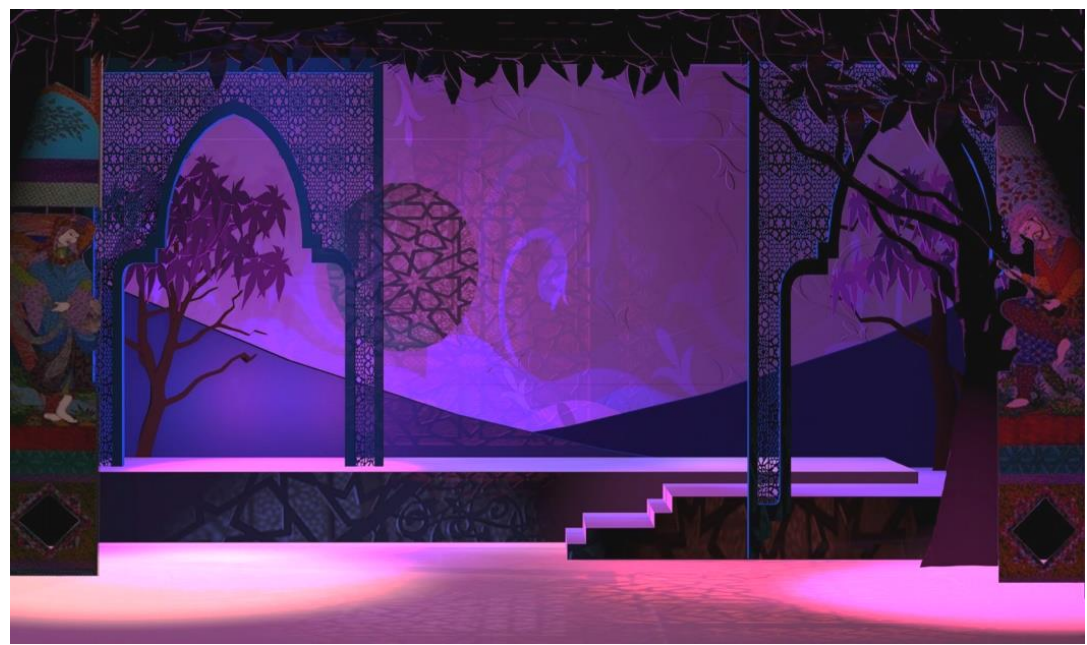

شكل 24: النموذج الرقمي للمنظر الر ابع الأمير الثاب و الأميرة الثابة

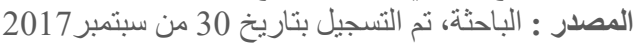

قامت الباحثة بعمل حالتين إضاءة مختلفتين للمنظر الرابع الأمير الثاب والأميرة الثابة ، يظلب عليهما الطابع الرومانسي الحالم الذب يتلائم مع الحالة

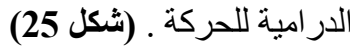
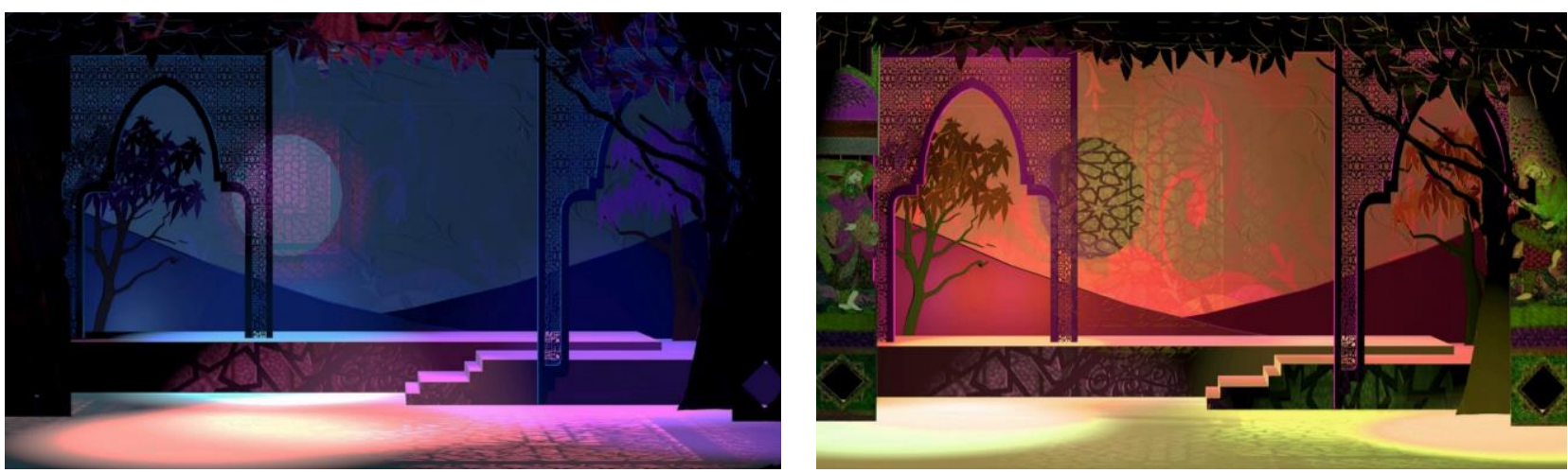

شكل 25: النموذج الرقمي للمنظر الر ابع الأمير الثناب و الأميرة الثابة في حالتين إضاءة مختلفتين

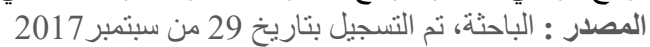

\section{المنظر الخامس : الاحتفالات في بغداد}

تبدأ الحركة الر ابعة في هذا المنظر لتوضح إحساسا باتساع المهرجان في بغداد ، يرتفع العزف وينخفض طبقا لما في أحداث المهرجان من إثارة ،

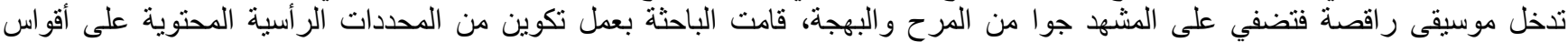

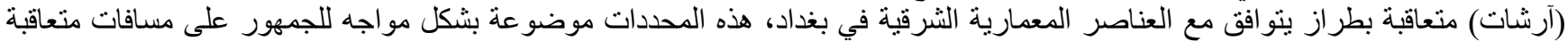

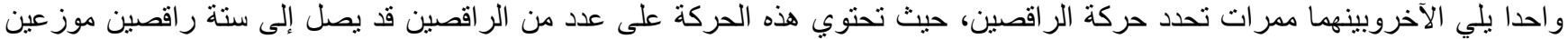

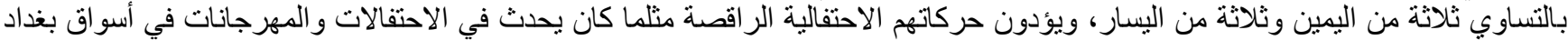

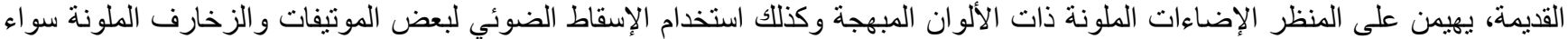

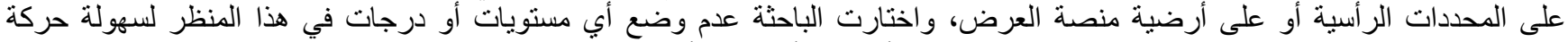

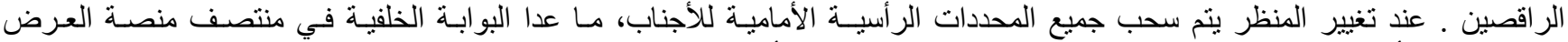

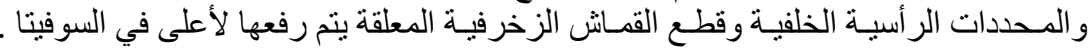




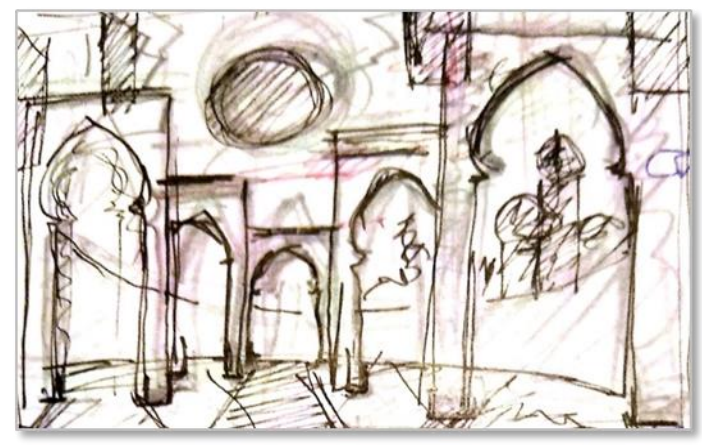

شكل 26: در اسة أولية من تصميم الباحثة للمنظر الخامس الاحتفالات في بغداد

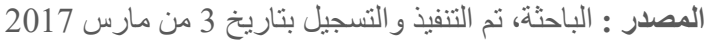

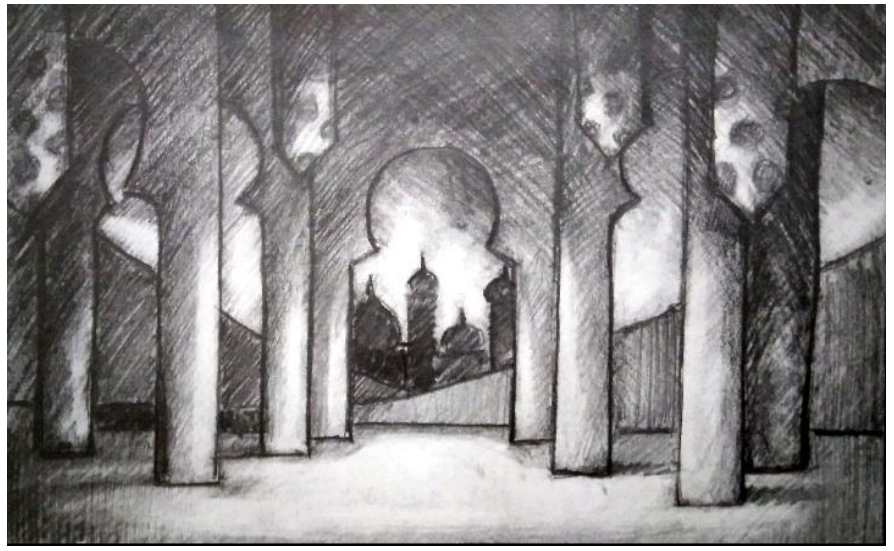

$$
\begin{aligned}
& \text { شكل 27: در اسة بالقلم الرصاص للمنظر الخامس الاحتفالات في بغداد، }
\end{aligned}
$$

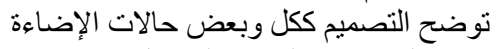

$$
\begin{aligned}
& \text { المصدر : الباحثة، تم التنفيذ و التسجيل بتاريخ } 8 \text { من بناير } 2017
\end{aligned}
$$
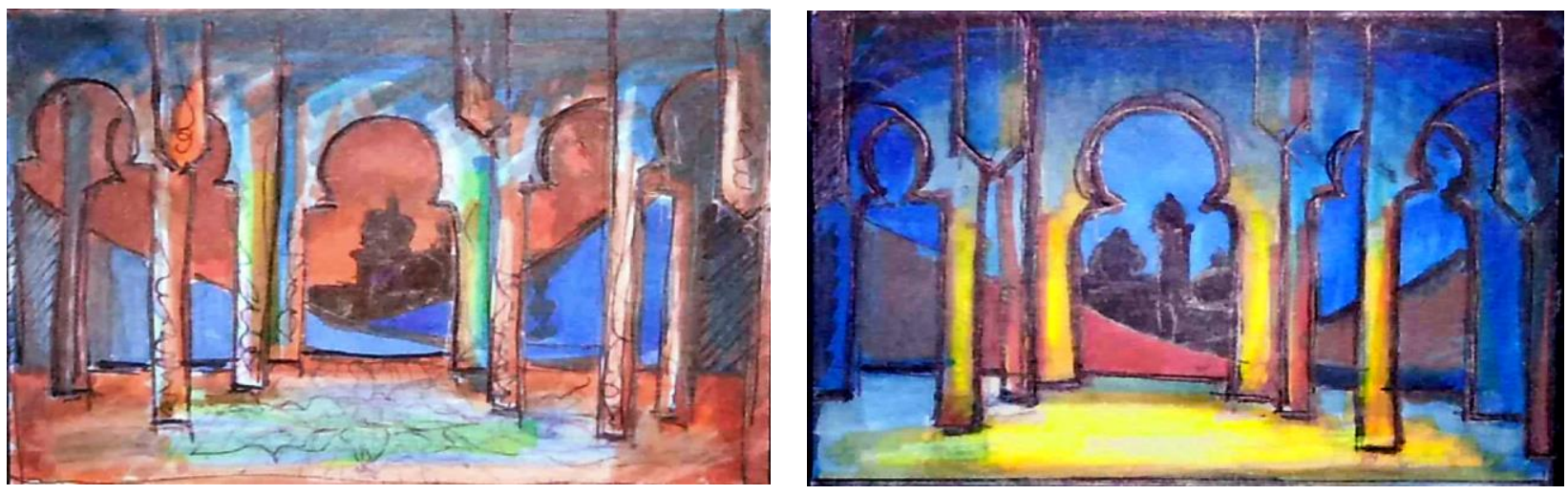

$$
\begin{aligned}
& \text { شكل 28: در اسات بالألوان Markers للمنظر الخامس الاحتفالات في بغداد، } \\
& \text { توضح التصميم ككل وبعض حالات الإضـاءة الإن الإن } \\
& \text { المصدر : الباحثّة، تم التنفيذ و التسجيل بتاريخ } 8 \text { من يناير } 2017
\end{aligned}
$$


W. S. Author, Paper Title; Vol. 8, R. 2020, Issue No. 1.

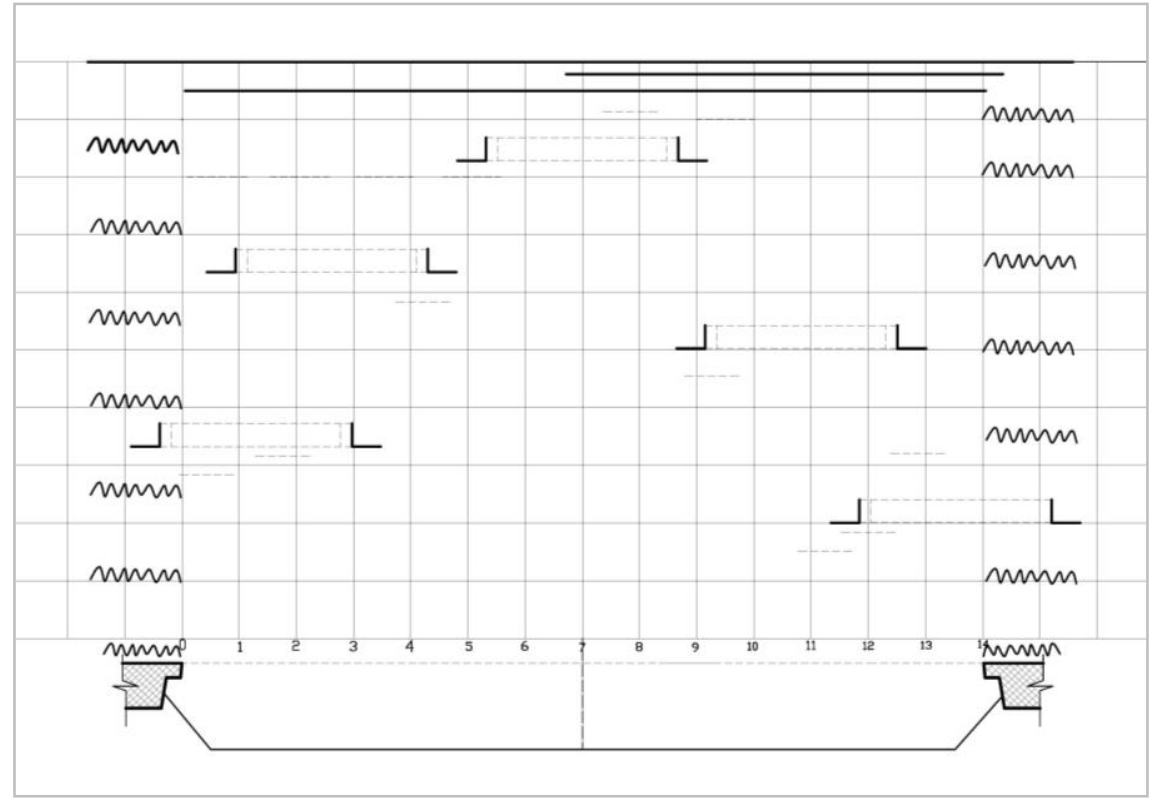

شكل 29: المسقط الأفقي الهندسي للمنظر الخامس الاحتفالات في بغداد

المصدر : الباحثة، تم التنفيذ والتشجيل بتاريخ 11 من سبتمبر 2017

في النموذج الرقمي بالإضاءة والخامات للمنظر الخامس الاحتفالات في بغداد ويظهر تكوين من المحددات الرأسية المحتوية على أقو اس (آرشات)

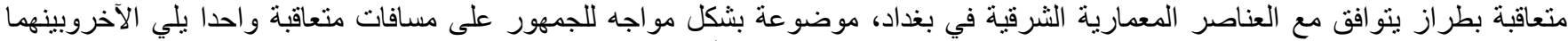

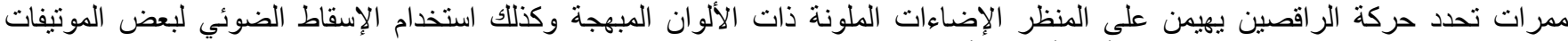

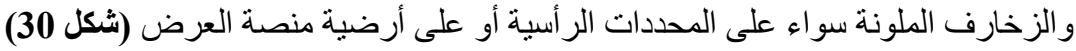

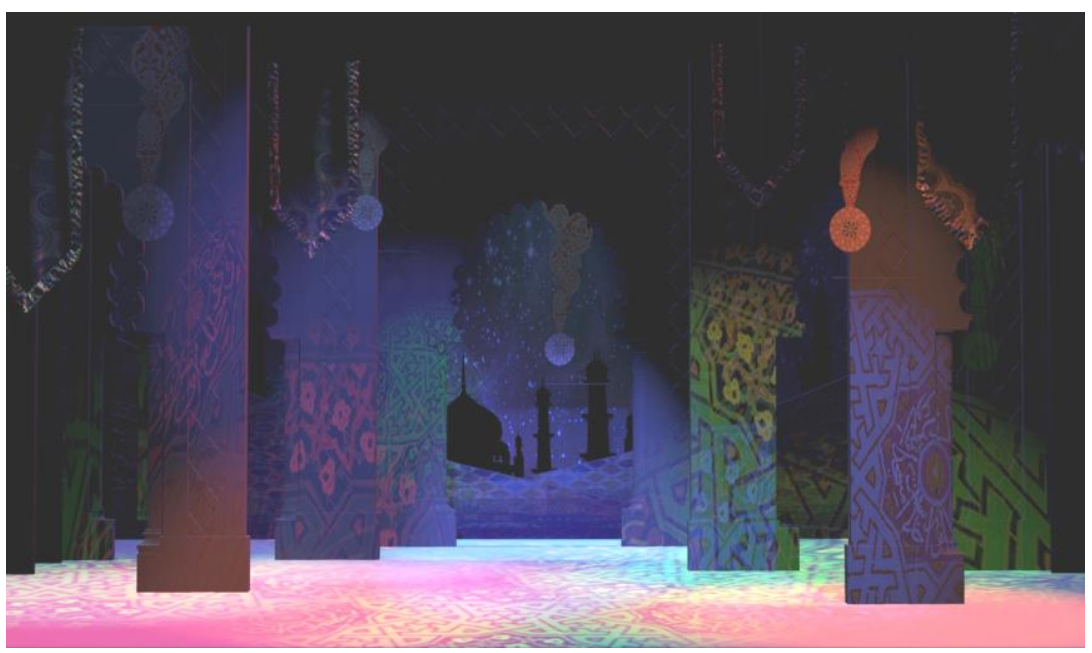

شكل 30: النموذج الرقمي للمنظر الخامس الاحتفالات في بغداد

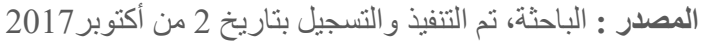

قامت الباحثة بعمل حالتين إضاءة مختلفتين للمنظر الرابع الاحتفالات في بغداد ، يغلب عليهما الطابع الاحتفالي المبهج الذي يتلائم مع الحالة الدرامية للحركة في أسواق بغداد أثناء الاحتفالات (شكل إضن 


\section{SJFA}
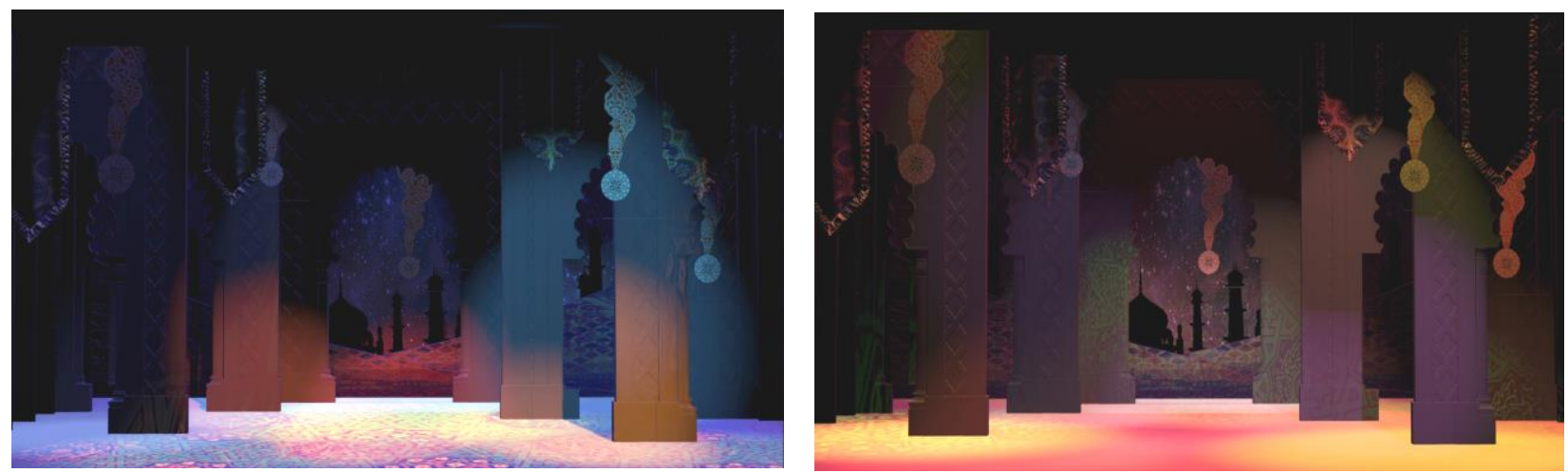

شكل 31: النموذج الرقمي للمنظر الخامس الاحتفالات في بغداد في حالتين إضـاءة مختلفتين

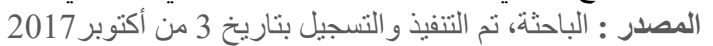

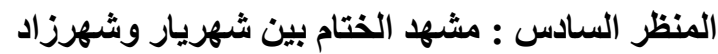

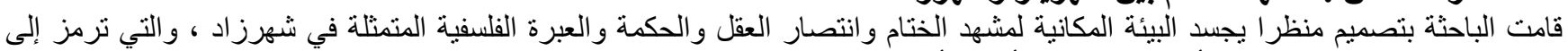

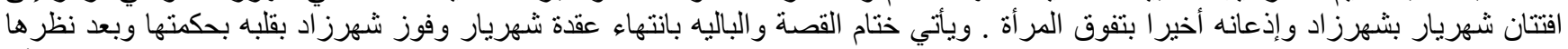

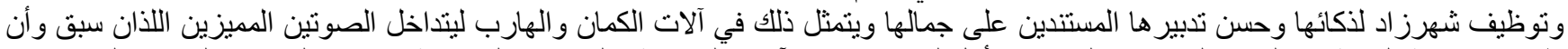

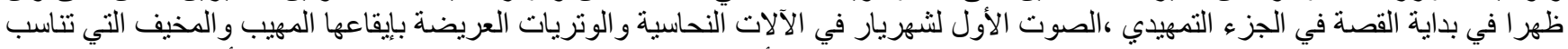

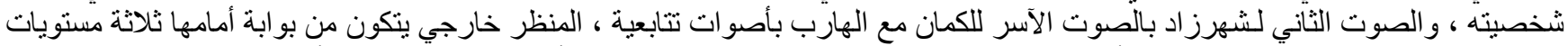

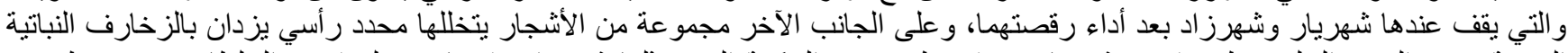

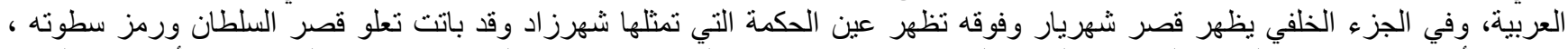

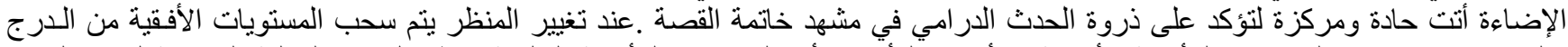

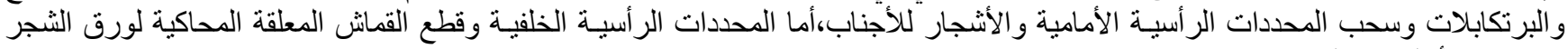

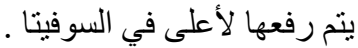

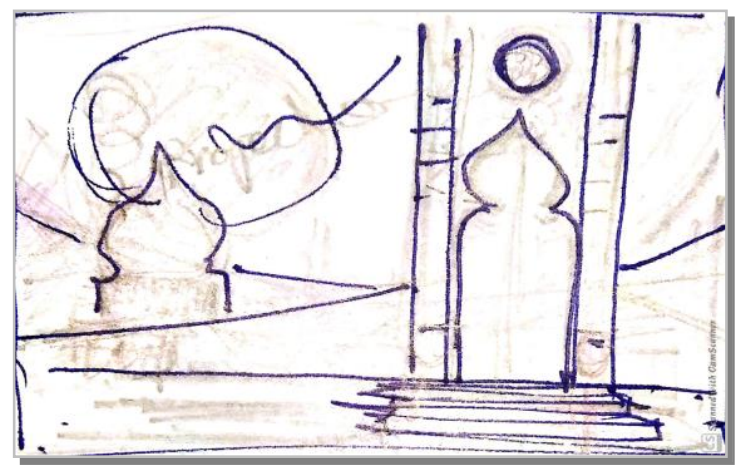

شكل 32: دراسة أولية من تصميم الباحثة للمنظر السادس مشهـ الختام بين شهريار وشهرز اد

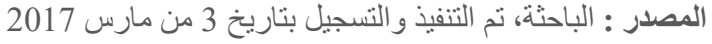


W. S. Author, Paper Title; Vol. 8, R. 2020, Issue No. 1.

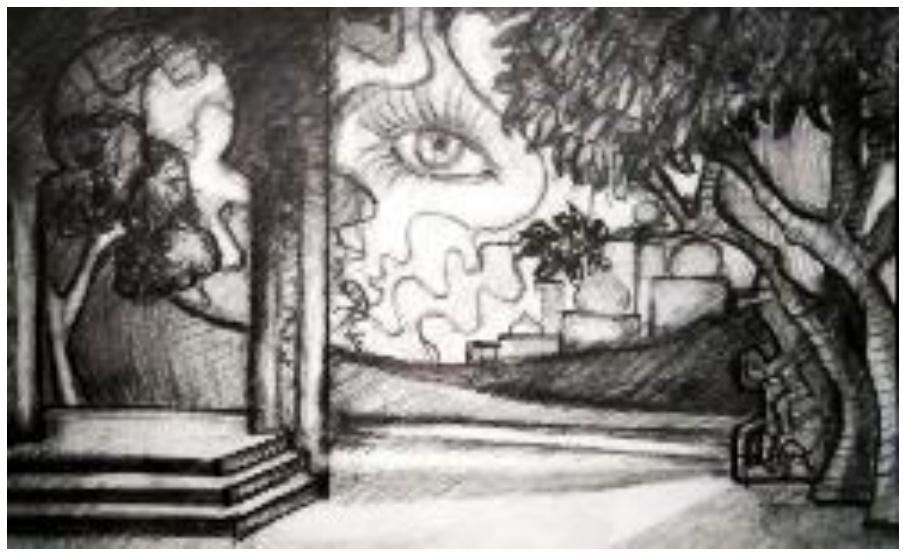

شكل 33: در اسة بالقلم الرصاص لمنظر السادس مشهر الختام بين شهريار وشهرز اد،

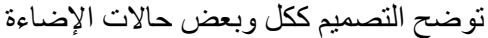

المصدر : الباحثة، تم التنفيذ و التسجيل بتاريخ 8 من يناير 2017
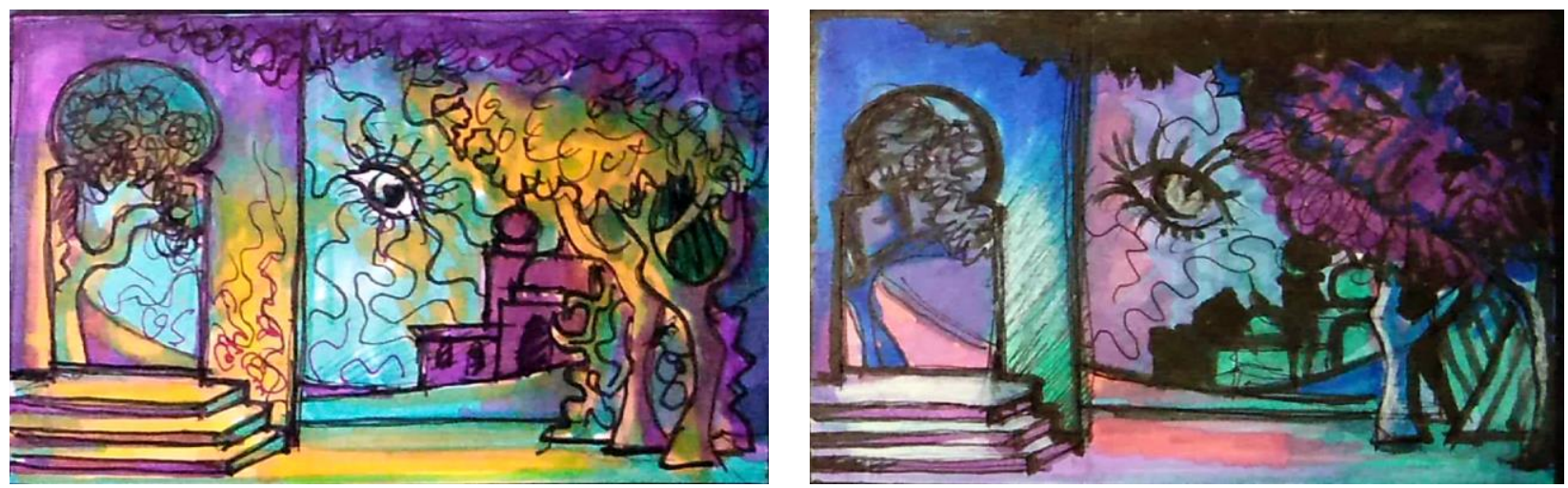

شكل 34: در اسة بالألو ان Markers للمنظر الساد مشهـ الختام بين شهريار وشهرز اد، توضح التصميم ككل وبعض حالات الإن الإضاءة التصني

المصدر : الباحثة، تم التنفيذ و التسجيل بتاريخ 8 من يناير الإعن 2017

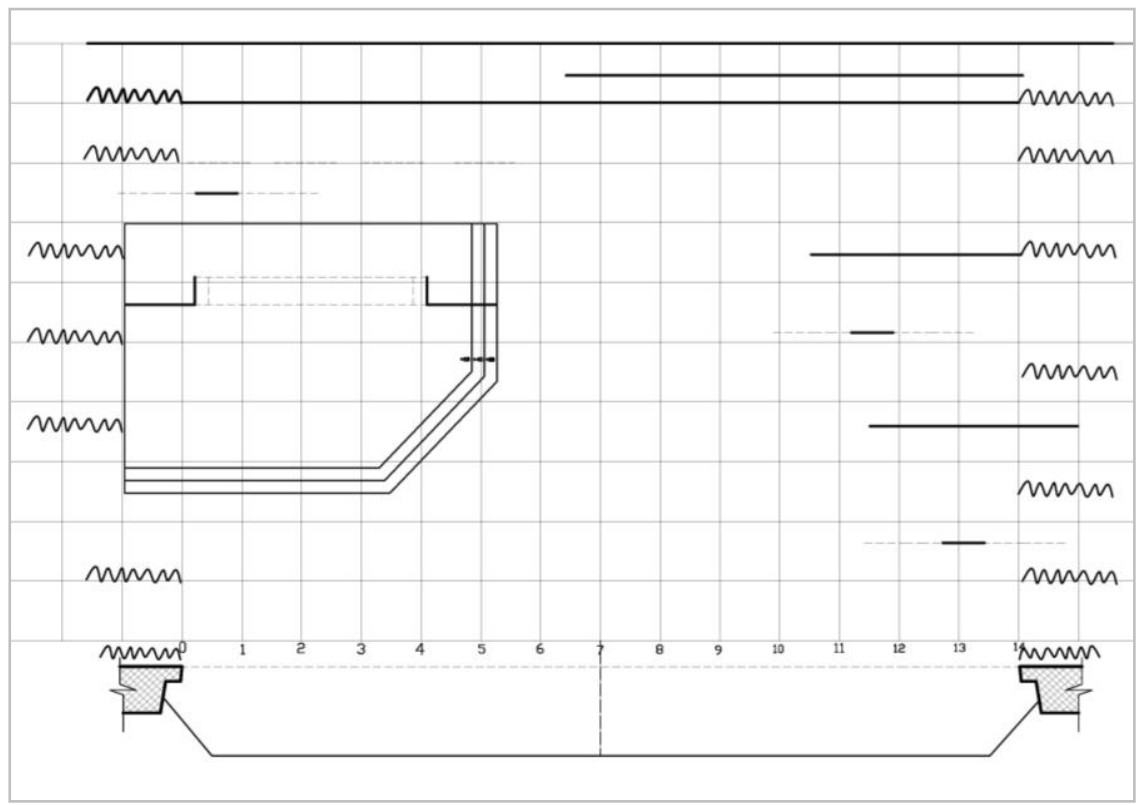

شكل 35: المسقط الأفقي الهندسي للمنظر السادس مشهد الختام بين شهريار وشهرزاد

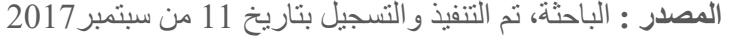




\section{SJFA}

في النموذج الرقمي بالإضاءة والخامات للمنظر السادس مشهر الختام بين شهريار وشهرزاد المنظر خارجي يتكون من بو ابة أمامها ثناثلثة مستويات

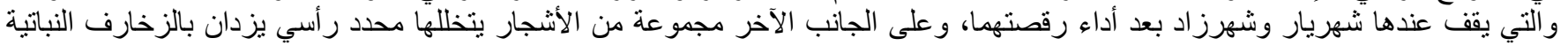
العربية، وفي الجزء الخلفي يظهر قصر شهريار وفوقه تظهر عين الحكمة التي تمثلها شهرز اد وقد باتت تعلو قصر السلطان ورمز سطوته (شكل 36)

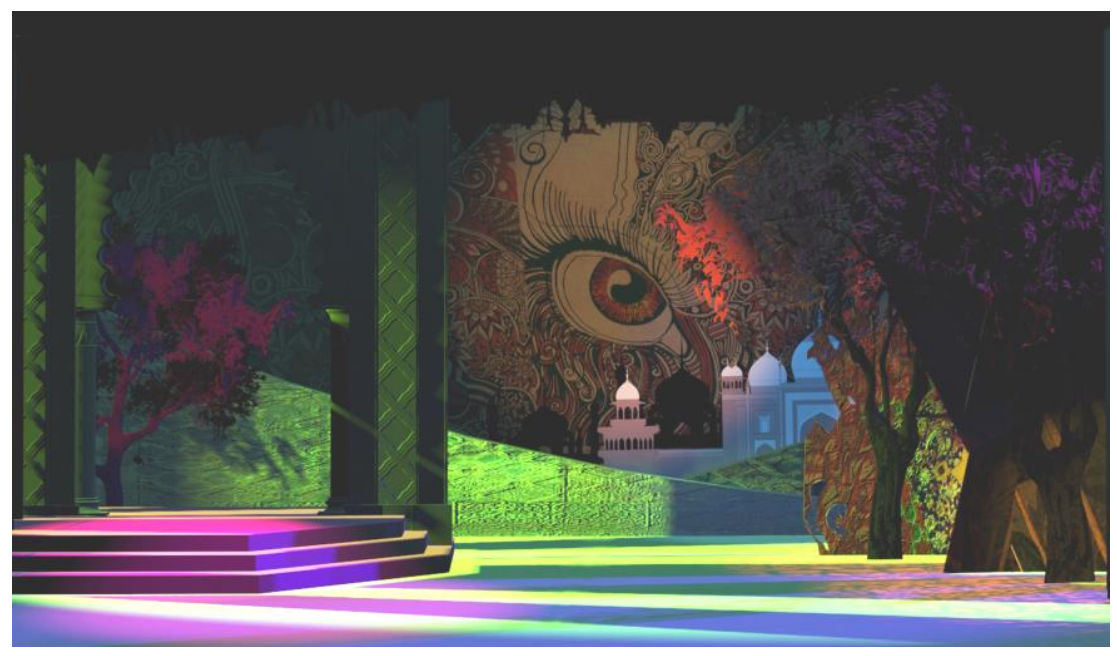

شكل 36: النموذج الرقمي للمنظر السادس مشهد الختام بين شهريار وشهرز اد المصدر : الباحثة، تم التنفيذ و التشجيل بتاريخ 5 من أكثوبر 2017

قامت الباحثة بعمل حالتين إضاءة مختلفتين للمنظر السادس مشهد الختام بين شهريار وشهرزاد ، يغلب عليهما الحدة والتركيز مؤكدة على ذروة

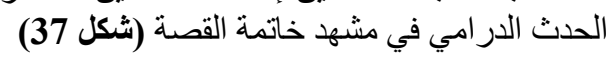
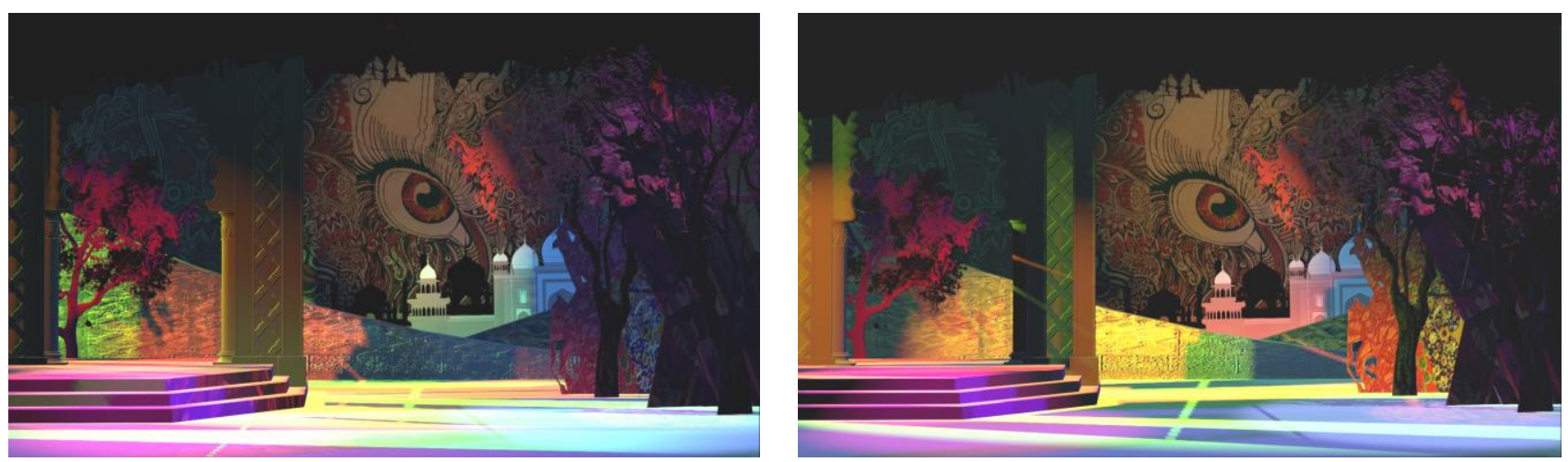

شكل 37: النموذج الرقمي للمنظر السادس مشهد الختام بين شهريار وشهرز اد في حالتين إضاءة مختلفتين المصدر : الباحثة، تم التنفيذ و التسجيل بتاريخ 3 من أكثوبر 2017 
W. S. Author, Paper Title; Vol. 8, R. 2020, Issue No. 1.

:

قامت الباحثة باختيار الكو لاج الورقي في تصميم أزياء الباليه لأنه مشابه لاختيار الأقمشة ذات النقاء النقشات و الألوان الملائمة وهذا الأسلوب يوفر إمكانية

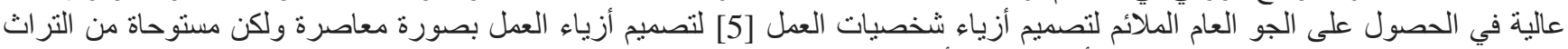

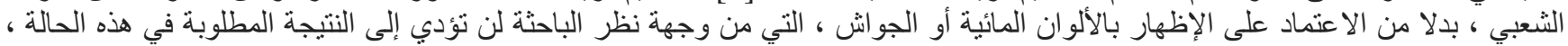

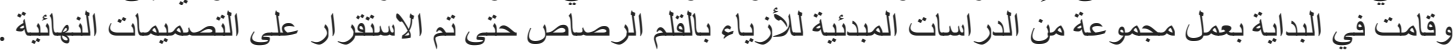
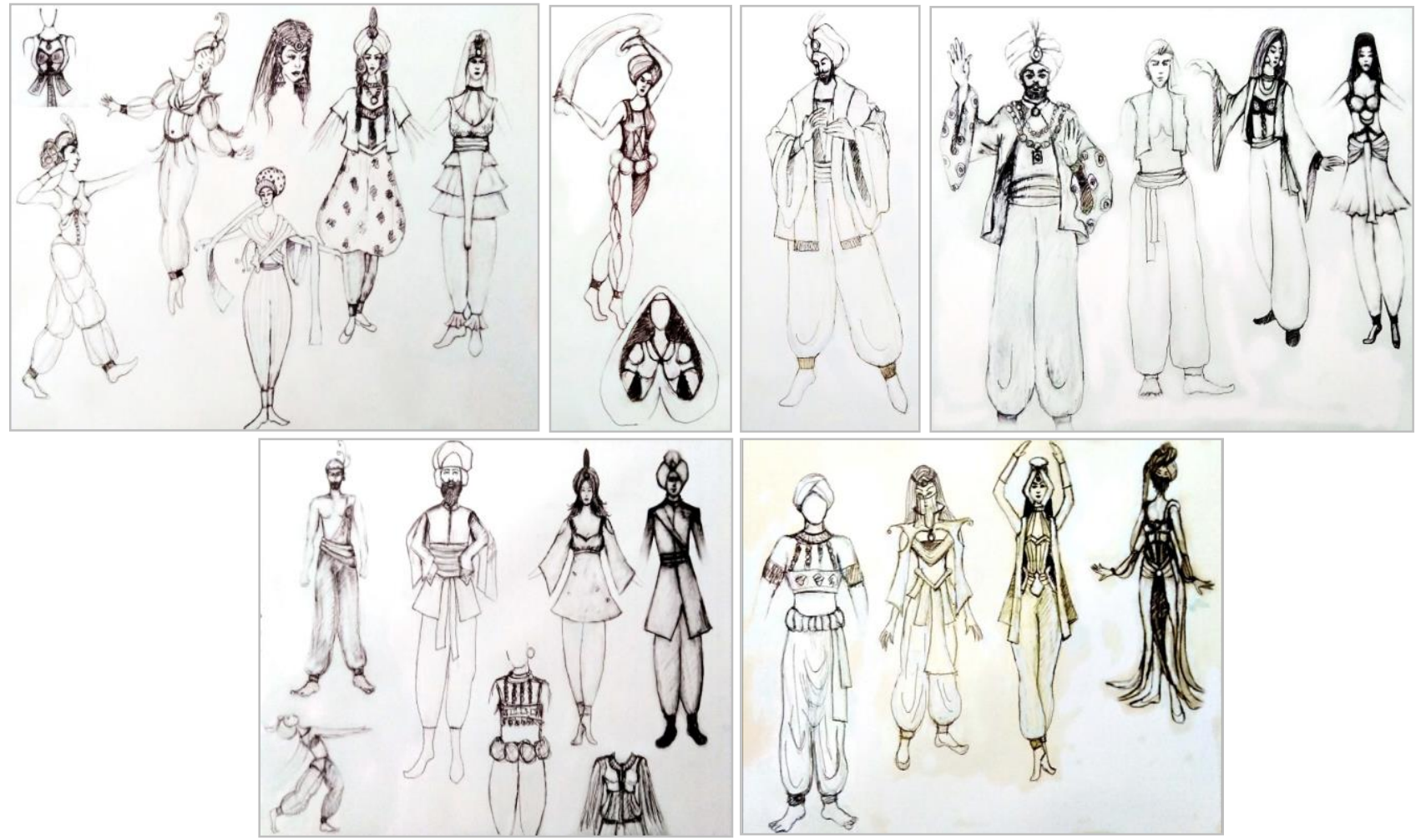

$$
\begin{aligned}
& \text { شكل 38: مجمو عة من الدر اسات المبئية للأزياء بالقلم الرصاص من تصميم الباحثة } \\
& \text { المصدر : الباحثة، تم التنفيذ و التسجيل بتاريخ } 5 \text { من مايو } 2017
\end{aligned}
$$

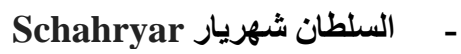

السلطان شهريار البطل الرئيسي في الحكايات ذو السطوة التي تمكنه من الزواج كل ليلة بفتاة بكر ليقتلها في الصباح التالي بسبب كر اهيته الثنديدة

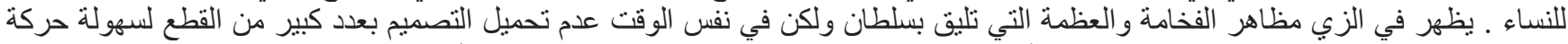

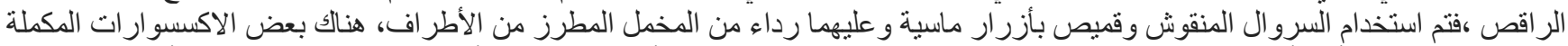

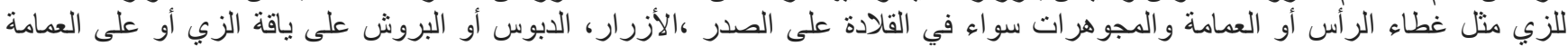

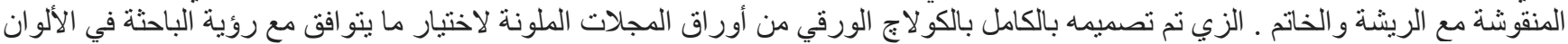
و الزخارف الخاصة بقماش الزئة الزي (شُكل 39 - أ)

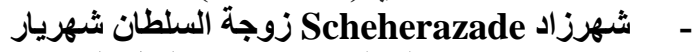

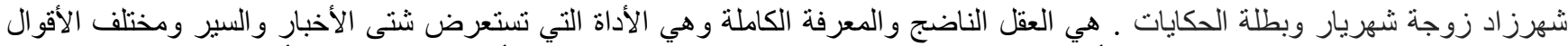

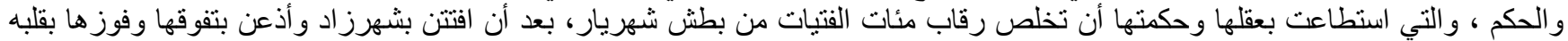

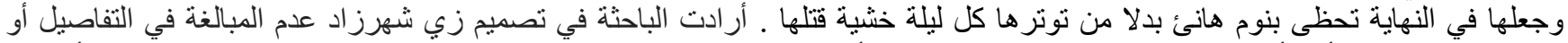

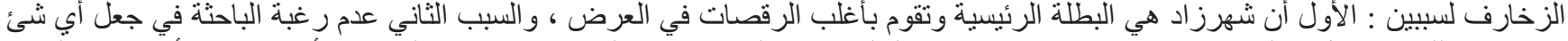

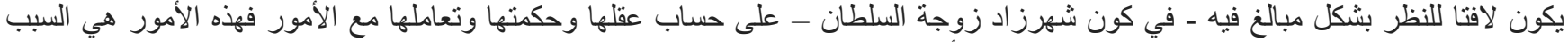

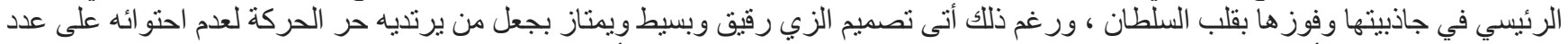

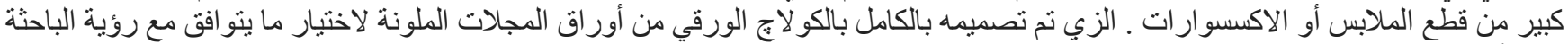

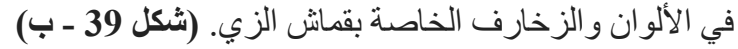




\section{SJFA}

Scientific Journal of the Faculty of Fine Arts Alexandria University

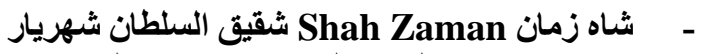

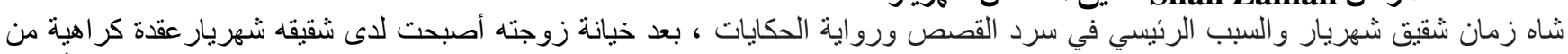

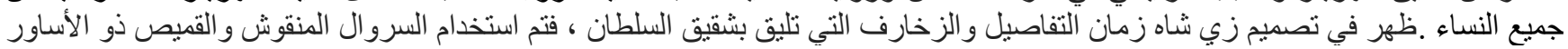

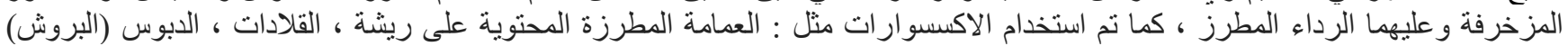

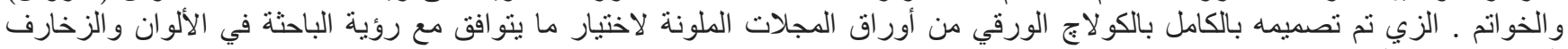

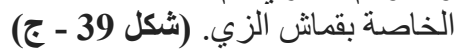

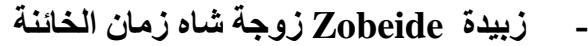

اللبب الرئبسي في سرد الحكايات ، بعد خيانتها لزوجها شاه زمان زمان شقيق شهريار أصبحت لاى شهريار عقدة كراهية من جميع النساء ، وبذللك تفاقم

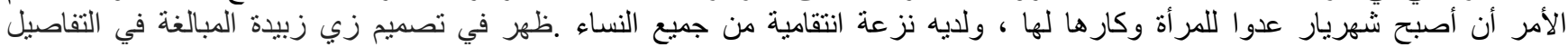

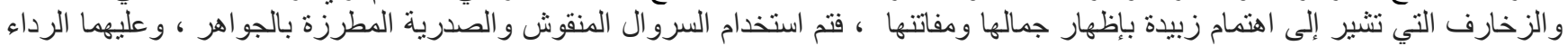

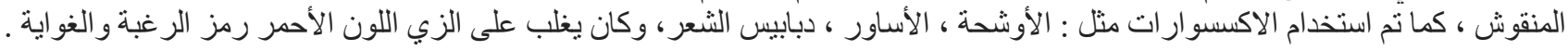

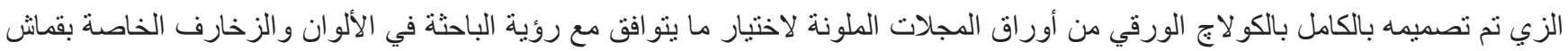

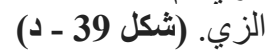

\section{Sinbad - -}

ظهر السندباد في الباليه ممثلا في شخصية شهريار نفسه في الحركة الأولى مؤديا أداءا حركيا بمصاحبة بعض البحارة البارة. أتى تصميم زي السندباد

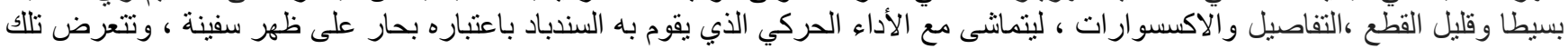

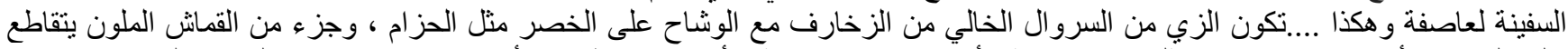

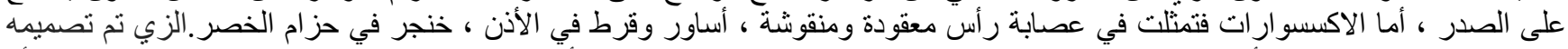

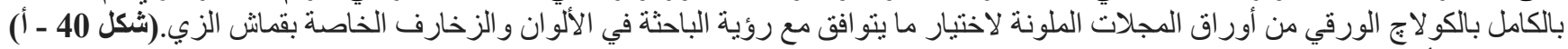

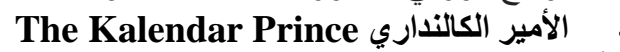

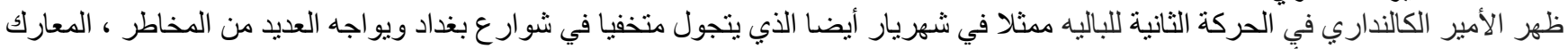

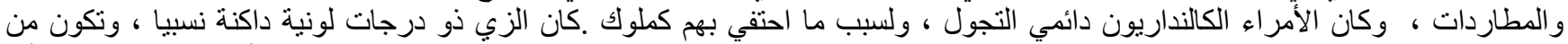

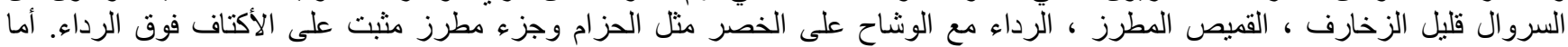

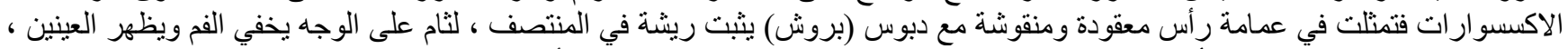

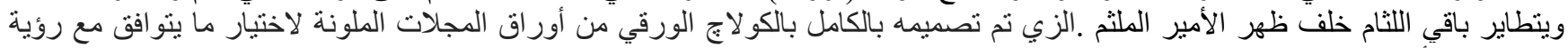

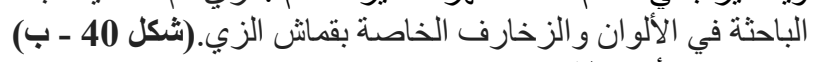

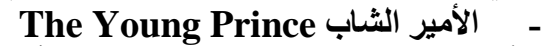

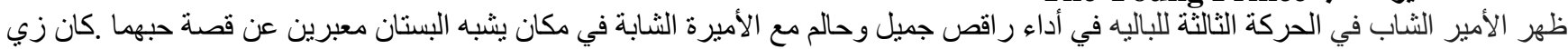

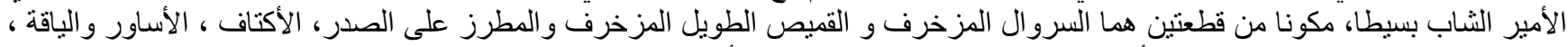

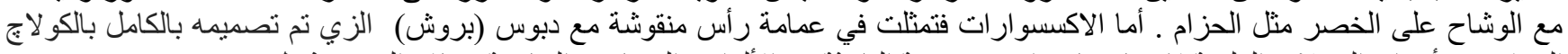

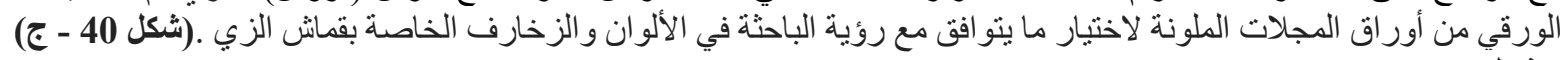

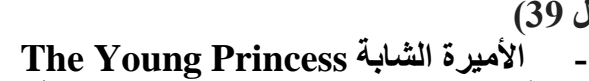

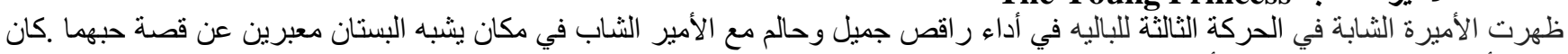

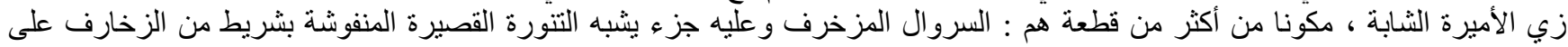

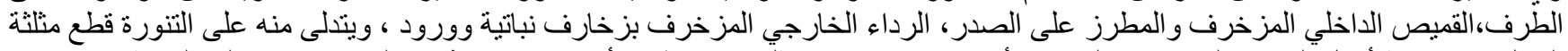

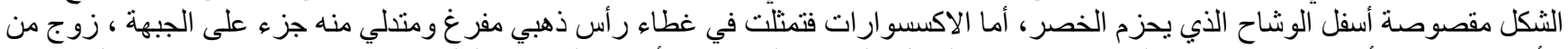

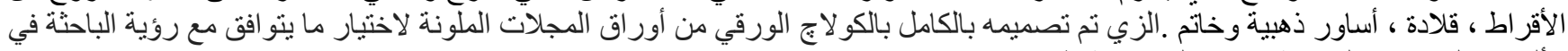

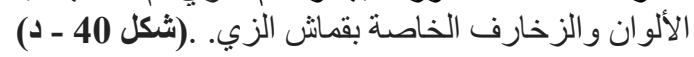


W. S. Author, Paper Title; Vol. 8, R. 2020, Issue No. 1.
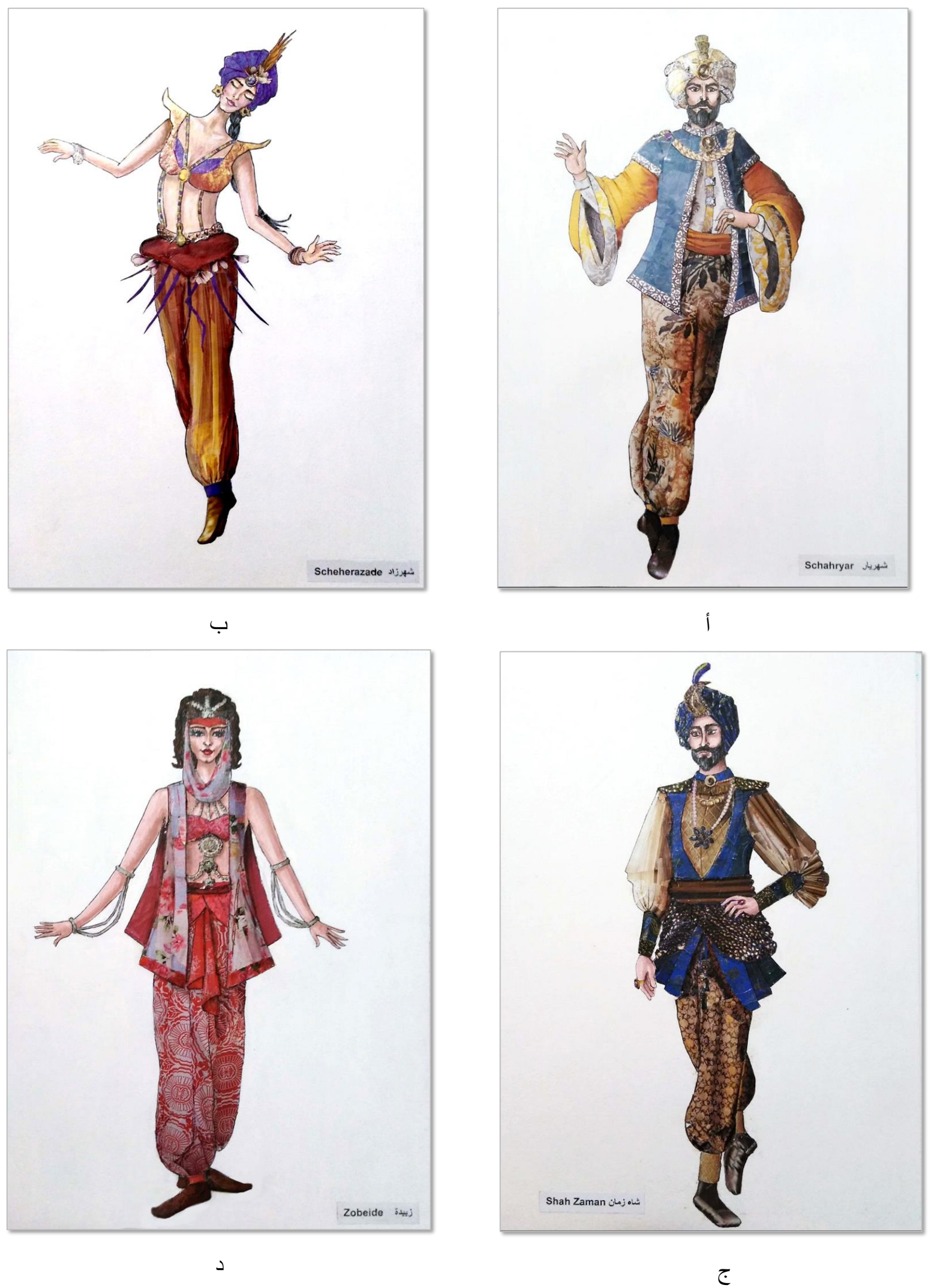

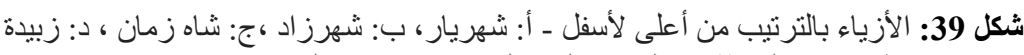

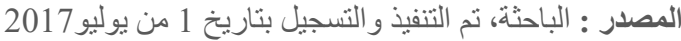




\section{SJFA}

Scientific Journal of the Faculty of Fine Arts Alexandria University
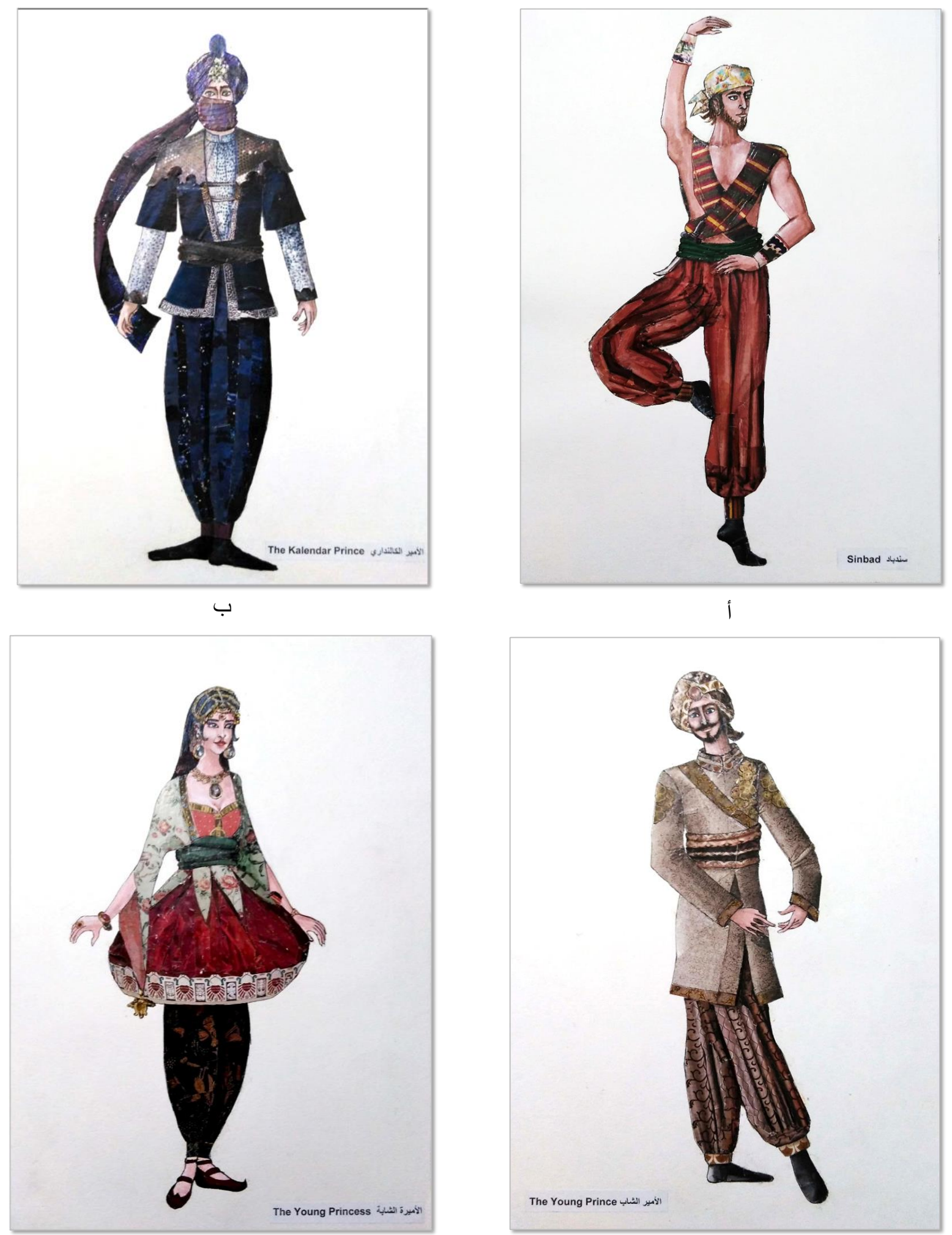

$د$

?

شكل 40: الأزياء بالترتيب من أعلى إلى أسفل ــ أ: السندباد، ب: الأمير الكالنداري ،ج: الأمير الثاب ، د: الأميرة الثـابة المصدر : الباحثة، تم التنفيذ و التسجيل بتاريخ 28 من بوليو 2017 
كتاب ألف ليلة وليلة هو وثثقة فنية و أثر أدبي للبيئة الثقافية والموروث الثعبي العربي ، ومن هنا فهي أصدق ارتباطا

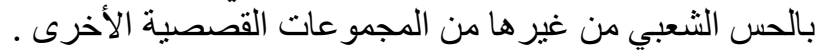

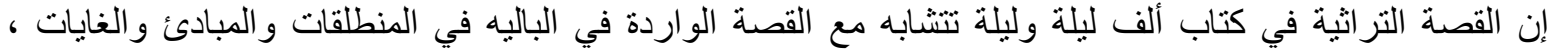

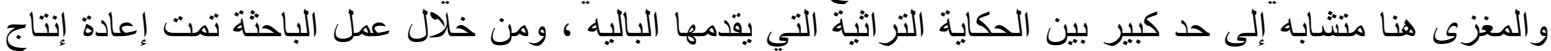

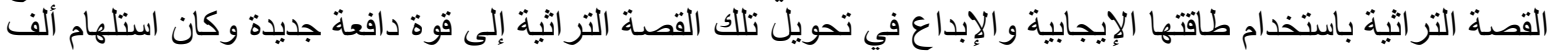

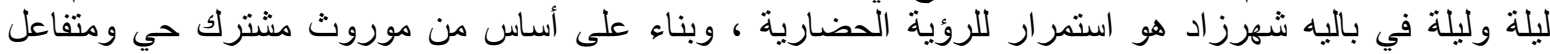
و ومتحرك دائما.

للتراث الثعبي أثر كبير في العرض المسرحي المعاصر فمن خلال البحث في الموروث الثران الثعبي القديم يمكن إيجاد

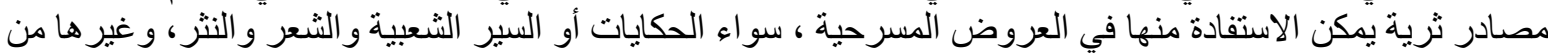

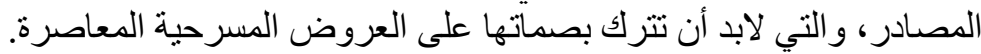

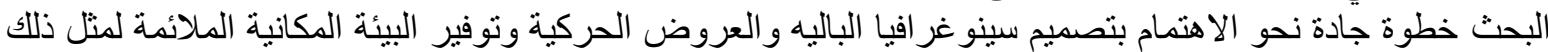

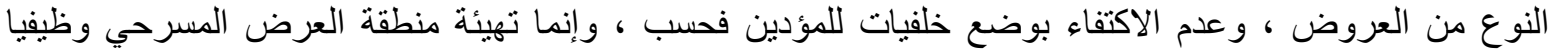

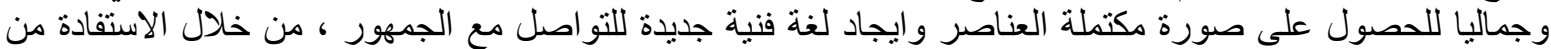

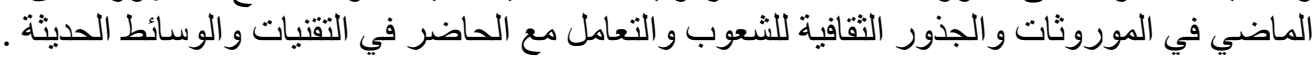

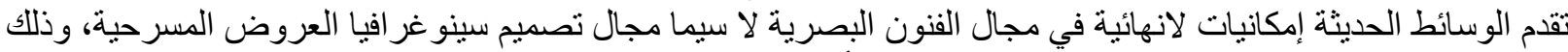

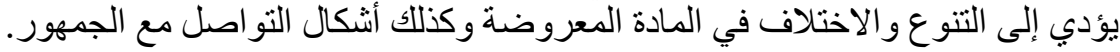

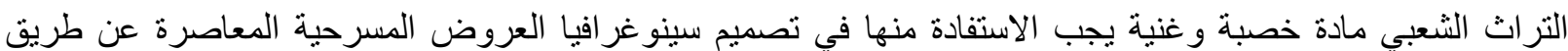

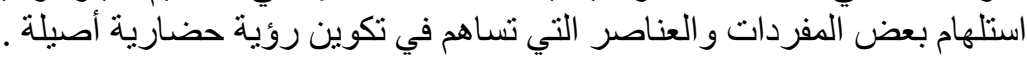

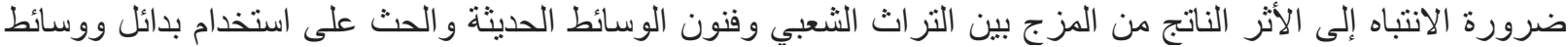
مختلفة لإظهار التصميمات المختلفة لسينوغر افيا العروض المسرحية المعاصرة ، سواء في تصميم المناظر أو الأزياء

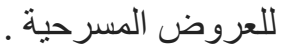

[Internet]. Ar.wikipedia.org. [cited 4 February 2017]. Available from: العوزي 1. https://ar.wikipedia.org/wiki/\%D9\%81\%D9\%88\%D8\%B2\%D9\%8A_\%D8\%A7\%D9\%84\%D8\%B9\%D9\%86\%D8 \%AA\%D9\%8A\%D9\%84

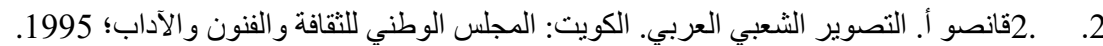

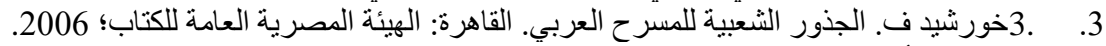

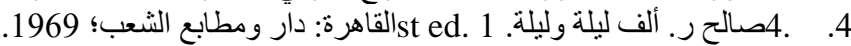

[Internet]. Ar.wikipedia.org. [cited 2 February 2017]. Available from: 5. 5. https://ar.wikipedia.org/wiki/\%D9\%86\%D9\%8A\%D9\%83\%D9\%88\%D9\%84\%D8\%A7\%D9\%8A_\%D8\%B 1\%D9\%8A\%D9\%85\%D8\%B3\%D9\%83\%D9\%8A_\%D9\%83\%D9\%88\%D8\%B1\%D8\%B3\%D8\%A7\%D9 $\% 83 \% D 9 \% 88 \%$ D9\%81

6. 6. [Internet]. Ar.wikipedia.org. [cited 12 March 2017]. Available from: https://ar.wikipedia.org/wiki/\%D8\%B4\%D9\%87\%D8\%B1\%D8\%B2\%D8\%A7\%D8\%AF_(\%D9\%85\%D9\%88\%D $8 \% \mathrm{~B} 3 \% \mathrm{D} 9 \% 8 \mathrm{~A} \% \mathrm{D} 9 \% 82 \% \mathrm{D} 9 \% 89)$

7. 7. Nutting J. Collage Couture. Cincinnati, Ohio: North Light Books; 2011.

8. 8. Synopsis: Scheherazade ballet [Internet]. Inspireddiversions.com. 2010 [cited 5 March 2017]. Available from: https://www.inspireddiversions.com/article.php?id_art=128 


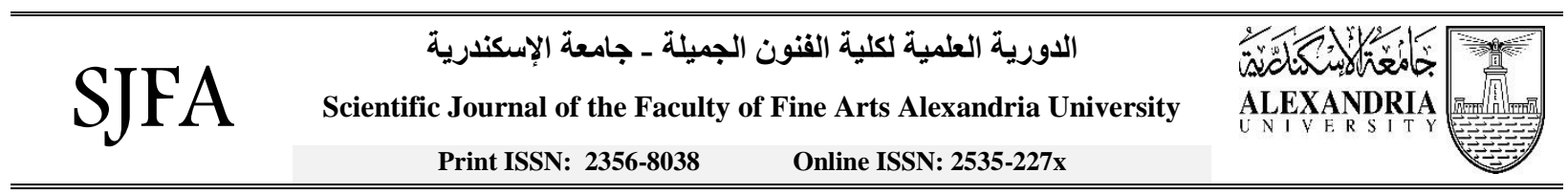

\title{
A vision of Scenography for Scheherazade ballet between Folklore and New Media
}

\author{
Basma Khalil Ebrahim²
}

\begin{abstract}
The "One Thousand and One Nights" book, which is an artistic document and a literary effect of the cultural environment and the Arab folk heritage, managed to occupy many scholars and researchers around the world, and inspired many artists to take from its material and tales a thread that they weave in many fields, such as the narrative literature for adults, children And the youth, and in theater, poetry, cinema, radio and television, it's also provided the fertile imagination of international music compositions, and colors of the art of dramatic movement such as ballet art.

The researcher designed the Scenography of "Scheherazade" ballet, which was represented in the studies of designing six scenes and eight costumes using modern media techniques in scenic design for ballet such as digital collage technology, which consisted in collecting and designing materials inspired by designs of elements of Arab folklore projected on the scenes and on the background curtain, taking into account the dramatic requirements and choreography for ballet, the number of performers in each scene and the paths of their movement, as well as changing the scenes. The paper collage technique was also used in the implementation of costume designs for performers after conducting its initial studies, to be an unusual mediator in fashion design and was able to create a new and different style in designing the costume inspired by the Arab and Persian folklore.
\end{abstract}

KEYWORDS: Ballet, Scenography, Collage, Folklore, Scenic design,Media

\footnotetext{
${ }^{2}$ Dr.Basma Khalil Ebrahim,lecturer,Décor department,Faculty of Fine Arts,Alexandria University Basma.khalil109@alexu.edu.eg
} 